\title{
CHARGE TRANSFER EXCITATION OF COORDINATION COMPOUNDS. GENERATION OF REACTIVE INTERMEDIATES
}

\section{Introduction}

Reactive compounds exhibit frequently catalytic properties. Particularly, many reactive metal complexes are characterized by their catalytic activity. Photochemistry presents one of the most important and versatile methods for the generation of reactive compounds. The design of photochemically generated catalysts requires a deeper insight in the photochemistry in general. The choice of appropriate light-sensitive precursors can be guided by several considerations. A straight-forward approach involves the selection of compounds according to the type of electronic excitation which often predetermines the nature of the photoproducts.

In a metal complex the metal-ligand bonds are generally polar. The molecular orbitals are then not equally delocalized between metal and ligands but predominantly located at the metal or the ligands. The electronic transitions are classified according to this localization [1]. In simple homoleptic mononuclear complexes three types of electronic excitations can be distinguished. Electronic transitions are localized at the metal (metalcentered, MC), at the ligand (ligand-centered, LC or intraligand, IL) or they take place between MOs at the metal and the ligand. The latter transitions are associated with a spatial redistribution of electrons and therefore are termed charge transfer (CT) transitions. While this review deals with CT excited states let us first have a short look at MC and LC states and their significance for the generation of reactive species which might be catalytically active.

Since the valence orbitals of metals may be of the $s, p, d$, and $f$ type all these orbitals can be involved in MC transitions. Ligand field (LF) or dd excited states have been investigated in great detail [2-6]. In many cases LF (or dd) excitation leads to a weakening of metal-ligand bonds. As a result a ligand may be released without any change of the oxidation state of the metal. This process is very important for the generation of catalysts because the product is a coordinatively unsaturated complex which provides an 
access for a suitable substrate. Other types of dd excited states may also lead to reactive intermediates. Binuclear complexes with a covalent metal-metal bond can be split homolytically by $\sigma^{b}{ }_{M-M} \rightarrow \sigma^{*}{ }_{M-M}$ excitation $[4,7]$. For example, the photolysis of $\mathrm{Mn}_{2}(\mathrm{CO})_{10}$ yields $\mathrm{Mn}(\mathrm{CO})_{5}$ radicals which recombine or engage in secondary reactions [4,7]. Much less is known on the photochemistry of MC excited states of the sp [8], pp [8], ds [9], dp or ff $[2,10]$ type. A better knowledge of these excited states will certainly lead to new catalytic applications.

LC excited states do not show a general pattern of reactivity. In many cases LC states occur at very high energies. LC excitation is then frequently followed by a facile deactivation to lower excited states of different origin. If an intraligand photoactivity is observed it is often similar to that of the free ligand but modified by coordination. For example,as free ligand and in the coordinated state stilbenecarboxylate can undergo a trans/cis photoisomerization [11]. However, the photostationary trans/cis ratio is influenced by the metal.

CT excited states can be viewed as energy-rich redox isomers of the ground state. The primary and frequently also the final products which result from CT excitation reflect the charge distribution in the excited state. Generally, these products are strongly reducing and/or oxidizing and their reactivity is directly connected to their redox properties. The following discussion of charge transfer states is presented in seven parts. In the first section CT absorption spectra are described. In the next part CT states are characterized on the basis of their emission spectra. This section is followed by a short description of different processes which lead to the generation of CT states. The reactivity of CT states is then discussed. Reactive intermediates generated by CT excitation are dealt with in the next part which is followed by a brief characterization of catalytically active species obtained by CT excitation. Finally, a conclusion and an outlook is given.

All subjects as outlined above are not covered comprehensively. They are rather illustrated by selected examples. This choice was guided by the authors' interest. In many cases our own observations are discussed in order to provide a competent review. Outer sphere (or intermolecular) CT interactions [12-18] are omitted since they are treated elsewhere in this book.

\section{Charge Transfer Absorption Spectra}

The concept of optical CT in metal complexes has been pioneered by Jørgensen [19]. CT transitions are classified according to the redox sites 
which are located at the metal and the ligands $[1,19]$. Jørgensen's scale of optical electronegativity can be used to estimate the energy of CT transitions $[1,19]$. Owing to the electronic coupling between metal and ligands the molecular orbitals are generally delocalized to a certain extent. Light absorption by a CT band involves then only transfer of a fraction of an electron between the redox sites at the metal and the ligands. In some cases MOs are completely delocalized and a CT description is not anymore appropriate.

In mononuclear homoleptic complexes only ligand-to-metal charge transfer (LMCT) and metal-to-ligand charge transfer (MLCT) transitions can occur. Polynuclear complexes which simultaneously contain an oxidizing and a reducing metal may display metal-to-metal charge transfer (MMCT) absorptions. Ligand-to-ligand charge transfer (LLCT) bands can be observed if a reducing and an oxidizing ligand are coordinated to a metal. Finally, a ligand itself can consist of a reducing and oxidizing part. As a result an intraligand charge transfer (ILCT) absorption may appear. While a comprehensive discussion of LMCT, MLCT, and MMCT transitions has been presented in Lever's book on inorganic electronic spectroscopy [1] LLCT and ILCT transitions have been treated briefly in a recent review [20]. In the present article the different types of charge transfer (CT) transitions are illustrated by selected examples with special reference to light-sensitive complexes.

\subsection{LIGAND-TO-METAL CHARGE TRANSFER (LMCT)}

Low-energy LMCT transitions occur if the metal is oxidizing and the ligand reducing. LMCT absorptions determine the color of many coordination compounds. LMCT bands can be classified according to the electron configuration at the metal. The most important configurations are included in our discussion.

\subsection{1. $d^{0}$}

Complexes with a $\mathrm{d}^{0}$ configuration contain a transition metal in the highest possible oxidation state. Since no valence electrons at the metal are left only LMCT transitions may occur (with the exception of ligand centered (LC) bands of complexes such as metalloporphyrins, see chapter 7 of this book). Typical examples are the tetrahedral oxo anions $\mathrm{MO}_{4}{ }^{\mathrm{n}-}$ and their thio 
Table 1 Longest wavelength LMCT absorptions $\left(\lambda_{\max }\right.$ in $n m$ ) of tetrahedral $d^{0}$ complexes [1,21]

\begin{tabular}{ll|ll}
\hline Complex & $\lambda_{\max }(\mathrm{nm})$ & Complex & $\lambda_{\max }(\mathrm{nm})$ \\
\hline $\mathrm{CrO}_{4}{ }^{2-}$ & 373 & $\mathrm{ReO}_{4}^{-}$ & 233 \\
$\mathrm{MoO}_{4}{ }^{2-}$ & 234 & $\mathrm{MoS}_{4}^{2-}$ & 469 \\
$\mathrm{WO}_{4}^{2-}$ & 199 & $\mathrm{WS}_{4}^{2-}$ & 395 \\
$\mathrm{MnO}_{4}^{-}$ & 529 & $\mathrm{ReS}_{4}^{2-}$ & 505 \\
\hline
\end{tabular}

derivatives $\mathrm{MS}_{4}{ }^{\mathrm{n}-}[1,21]$. Table 1 presents some representative absorption maxima in this group of complexes.

The ligand-to-metal charge transfer (LMCT) bands are shifted to longer wavelength with an increase of the oxidizing power of the metal (e.g. $\mathrm{Mo}(\mathrm{VI})<\mathrm{Cr}(\mathrm{VI})<\mathrm{Mn}(\mathrm{VII}))$ and of the reducing strength of the ligand $\left(\mathrm{O}^{2-}\right.$ $\left.<\mathrm{S}^{2-}\right)$. Since, however, the metal-ligand bonds of these anions are hardly polar the extent of charge redistribution which is associated with a LMCT transition is rather small. The lowest-energy LMCT transition does not terminate at pure metal orbitals but at a MO which is $\mathrm{M}-\mathrm{L} \pi$-antibonding [1]. This is nicely illustrated by the vibrational structure of the absorption bands. (e.g. $\mathrm{ReO}_{4}^{-}$, Fig. 1 [22]). In the ligand-to-metal CT state the metal-ligand bonds are weakened as indicated by the spacing of this vibrational progression.

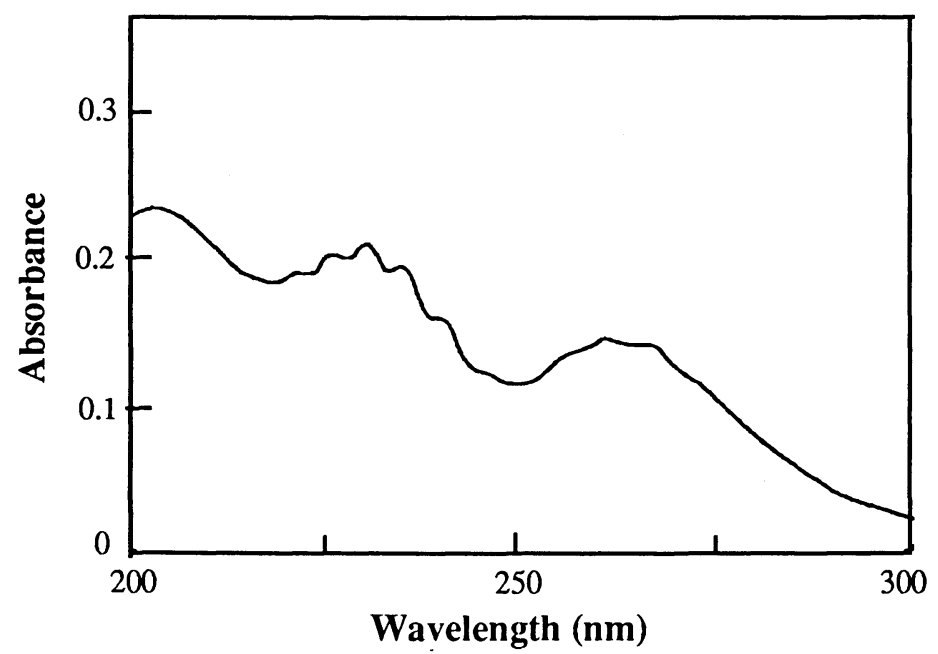

Figure I Electronic absorption spectrum of $1.42 \times 10^{-4} \mathrm{M} \mathrm{CH}_{3} \mathrm{ReO}_{3}$ in $\mathrm{n}$-hexane at room temperature (1-cm cell). 


\subsection{2. $d^{5}$}

Octahedral low-spin $\mathrm{d}^{5}$ complexes display frequently characteristic longwavelength LMCT bands [1]. The low energy of these transitions is related to the nature of the acceptor orbital. These $\pi_{\mathrm{d}}$ orbitals are not only rather stable but have only a small effect on the metal-ligand bonding. The reorganizational energy is then quite small and contributes hardly to the energy of the LMCT transition. Typical examples are $\left[\mathrm{Fe}(\mathrm{CN})_{6}\right]^{3-}\left(\lambda_{\max }=\right.$ $420 \mathrm{~nm})[23]$ and $\left[\mathrm{Ru}\left(\mathrm{NH}_{3}\right)_{5} \mathrm{X}\right]^{2+}$ with $\mathrm{X}=\mathrm{Cl}\left(\lambda_{\max }=328 \mathrm{~nm}\right), \mathrm{Br}(398$ $\mathrm{nm})$, and I (541 nm) [1,24]. Even organometallic compounds such as $\mathrm{Cr}(\mathrm{CO})_{5} \mathrm{I}\left(\lambda_{\max }=638 \mathrm{~nm}\right.$, Fig. 2 [25]) which contains the metal in a low oxidation state show such long-wavelength LMCT bands . However, the appearance of low-energy LMCT bands is not limited to octahedral low-spin complexes. Irrespective of the particular complex Fe(III) compounds generally display long-wavelength LMCT absorptions due to the oxidizing nature of the metal [1].

\subsection{3. $d^{6}$}

Octahedral low-spin $\mathrm{d}^{6}$ complexes show LMCT bands at relatively short wavelength since the acceptor orbital $\sigma_{\mathrm{d}}{ }^{*}$ occurs at rather high energies and has a large influence on the metal-ligand bonding. The reorganizational

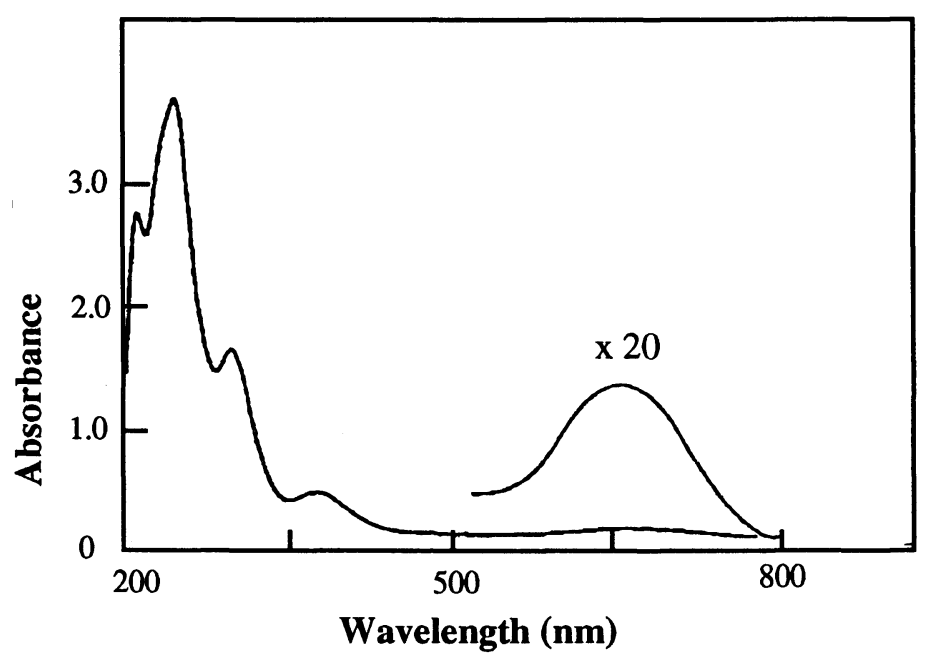

Figure 2 Electronic absorption spectrum of $1.04 \times 10^{-4} \mathrm{M}\left[\mathrm{Cr}(\mathrm{CO})_{5}\right]$ in $\mathrm{CH}_{3} \mathrm{CN}$, argonsaturated solution. 
Table 2 Longest-wavelength halide-to-metal LMCT absorptions ( $\lambda_{\max }$ in $\mathrm{nm}$ ) of octahedral $d^{6}$ complexes $[1,21]$

\begin{tabular}{ll|ll}
\hline Complex & $\lambda_{\max }(\mathrm{nm})$ & Complex & $\lambda_{\max }(\mathrm{nm})$ \\
\hline$\left[\mathrm{Co}\left(\mathrm{NH}_{3}\right)_{5} \mathrm{Cl}\right]^{2+}$ & 270 & {$\left[\mathrm{PtCl}_{6}\right]^{2-}$} & 270 \\
{$\left[\mathrm{Co}\left(\mathrm{NH}_{3}\right)_{5} \mathrm{Br}\right]^{2+}$} & 313 & {$\left[\mathrm{PtBr}_{6}\right]^{2-}$} & 327 \\
{$\left[\mathrm{Co}\left(\mathrm{NH}_{3}\right)_{5}\right]^{2+}$} & 383 & {$\left[\mathrm{PtI}_{6}\right]^{2-}$} & 494 \\
\hline
\end{tabular}

energy is then quite large and contributes considerably to the energy of LMCT transitions. So it is not surprising that LMCT absorptions of $\mathrm{Co}$ (III) and Pt(IV) complexes appear frequently in the UV region (Table $2[1,21]$ ).

\subsection{4. $d^{10}$}

Since metals such as $\mathrm{Au}(\mathrm{I})$ and $\mathrm{Hg}(\mathrm{II})$ have completely filled d shells LMCT transitions must terminate at the next higher $\mathrm{s}$ orbital of the metal. $\mathrm{Au}(\mathrm{I})$ complexes of the type $\left[\mathrm{AuX}_{2}\right]^{-}$with $\mathrm{X}=$ halide show such LMCT bands at energies comparable to those of MC ds transitions [26]. The $\mathrm{d}^{10}$ orbitals of mercury are much more stable and do not participate in low-energy electronic transitions. Consequently, the absorption spectra of simple $\mathrm{Hg}^{2+}$ complexes contain only LMCT bands, e.g. $\left[\mathrm{Hg}\left(\mathrm{N}_{3}\right)_{3}\right]^{-}\left(\lambda_{\max }=246 \mathrm{~nm}\right.$, Fig. 3 [27]).

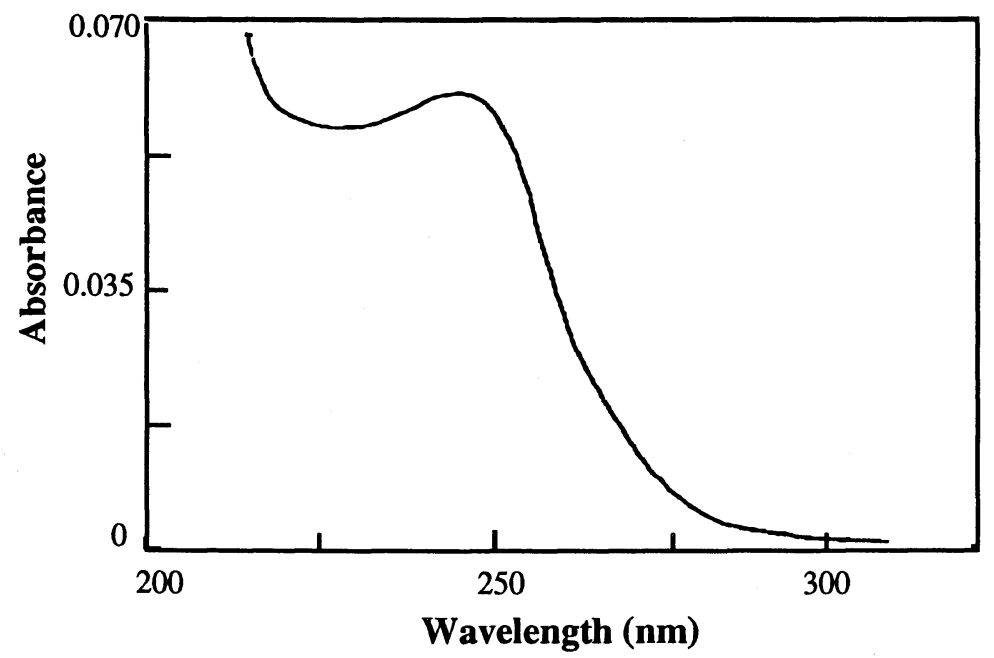

Figure 3 Electronic absorption spectrum of $\left.1.04 \times 10^{-5} \mathrm{M}\left[\mathrm{NBu}_{4}\right]\left[\mathrm{HgN}_{3}\right)_{3}\right]$ in ethanol. 


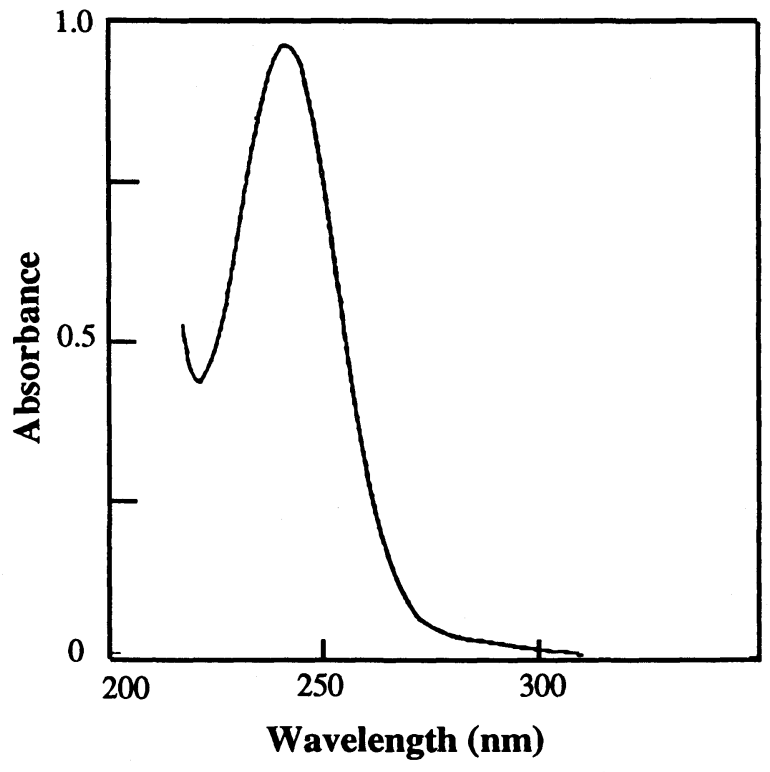

Figure 4 Electronic absorption spectrum of $2.17 \times 10^{-4} \mathrm{M} \mathrm{K}_{3}\left[\mathrm{TICl}_{4}\right]$ in saturated aqueous $\mathrm{KCl}$ solution.

\subsection{5. $s^{0}$}

$\mathrm{Au}^{+}$and $\mathrm{Hg}^{2+}$ may be also classified as $\mathrm{s}^{0}$ metals. However, in order to distinguish between d-block and main group metals the designation $s^{0}$ is reserved for main group elements in their highest oxidation state. Owing to the absence of valence electrons at the metal, $\mathrm{s}^{0}$ complexes such as $\left[\mathrm{TlCl}_{4}\right]^{-}$ $\left(\lambda_{\max }=247 \mathrm{~nm}\right.$ [28], Fig. 4) show only LMCT bands [29]. A few other typical examples are given in Table 3 [28-31].

\subsection{6. $s^{2}$}

LMCT transitions of $s^{2}$ complexes terminate at the empty $\mathrm{p}$ orbitals of the

Table 3 Longest-wavelength halide-to-metal LMCT absorptions ( $\lambda_{\max }$ in $\mathrm{nm}$ ) of octahedral $s^{0}$ complexes [28-31]

\begin{tabular}{ll|ll}
\hline Complex & $\lambda_{\max }(\mathrm{nm})$ & Complex & $\lambda_{\max }(\mathrm{nm})$ \\
\hline$\left[\mathrm{SnCl}_{6}\right]^{2-}$ & 278 & {$\left[\mathrm{~Pb}\left(\mathrm{~N}_{3}\right)_{6}\right]^{2-}$} & 390 \\
$\left.\left[\mathrm{Sn}^{2} \mathrm{~N}_{3}\right)_{6}\right]^{2-}$ & 264 & {$[\mathrm{SbCl} 6]^{3-}$} & 272 \\
{$\left[\mathrm{PbCl}_{6}\right]^{2-}$} & 307 & & \\
\hline
\end{tabular}


metal. Generally, such LMCT bands appear at very short wavelength and may be obscured by MC-centered sp absorptions [29]. $\mathrm{TeBr}_{6}{ }^{2-}$, for example, displays a LMCT band at $\lambda_{\max }=270 \mathrm{~nm}[32,33]$.

\subsection{7. $f^{n}$}

Complexes of oxidizing $\mathrm{f}^{\mathrm{n}}$ metals such as $\mathrm{Ce}(\mathrm{IV}), \mathrm{U}(\mathrm{VI})\left(\mathrm{f}^{0}\right)$ or $\mathrm{Eu}(\mathrm{III})\left(\mathrm{f}^{6}\right)$ are characterized by low-energy LMCT transitions which terminate at the empty or partially filled $\mathrm{f}$ shell of the metal, e.g. $\left[\mathrm{UO}_{2}\right]^{2+}$ in aqueous $\mathrm{HClO}_{4}$ $\left(\lambda_{\max }=415 \mathrm{~nm}\right)[34,35]$ and $\left[\mathrm{Eu}\left(\mathrm{H}_{2} \mathrm{O}\right)_{n}\right]^{3+}\left(\lambda_{\max }=190 \mathrm{~nm}\right)[36]$.

\subsection{METAL-TO-LIGAND CHARGE TRANSFER (MLCT)}

MLCT absorptions appear at long wavelength if the metal is reducing and the ligands (e.g. $\mathrm{CO}, \mathrm{CN}^{-}$, olefins, 2,2'-bipyridyl) provide rather stable empty orbitals which are mostly of the $\pi^{*}$ type [1]. The position of MLCT bands may depend on the solvent polarity [1]. Many complexes with MLCT bands, in particular cyano complexes, display also charge transfer to solvent (CTTS) bands $[4,37,38]$. The distinction between MLCT and CTTS transitions is not always clear since the MLCT acceptor orbital is also exposed to and influenced by the solvent. Even other transitions of quite different origin can be considered to have some MLCT contribution. Rydberg (or inter- configurational) MC transitions of the $\mathrm{nd}^{10} \rightarrow \mathrm{nd}^{9}(\mathrm{n}+1) \mathbf{s}^{1}$ type (e.g. $\mathrm{Cu}(\mathrm{I}))$ should contain some MLCT [39] or CTTS [40] character due to the diffuseness of the $(n+1) s$ orbitals. LF $\left(d_{\pi}-d_{\sigma}{ }^{*}\right)$ transitions of octahedral complexes are also associated with a small shift of electron density from the metal to the ligand since $d_{\sigma}{ }^{*}$ orbitals are mixed considerably with ligand orbitals while the ligand content of $\mathrm{d}_{\pi}$ orbitals is generally much smaller. The majority of complexes which display typical MLCT spectra include those of reducing $\mathrm{d}^{6}, \mathrm{~d}^{8}, \mathrm{~d}^{10}$, and $\mathrm{s}^{2}$ metals. Especially organometallic compounds with metals in low oxidation states and $\pi$-acceptor ligands are often characterized by long-wavelength MLCT absorptions $[1,4]$.

\subsection{1. $d^{6}$}

Octahedral low-spin $d^{6}$ complexes with a reducing metal center (e.g. $\mathrm{Cr}(\mathrm{O})$, $\mathrm{Mo}(\mathrm{O}), \mathrm{W}(\mathrm{O}), \mathrm{Mn}(\mathrm{I}), \operatorname{Re}(\mathrm{I}), \mathrm{Fe}(\mathrm{II}), \mathrm{Ru}(\mathrm{II})$, and $\mathrm{Os}(\mathrm{II})$ and polypyridyl (or 1,2-diimine) ligands (e.g. 2,2'-bipyridyl, 1,10-phenanthroline) represent 
the largest family of compounds with low-energy $\mathrm{M} \rightarrow \mathrm{L}$ charge transfer transitions $[1,3,4,12,41]$. These compounds are frequently colored since their MLCT bands appear in the visible region. For a detailed discussion the reader is referred to other chapters of this book. It is remarkable that $\mathbf{M} \rightarrow$ bipy MLCT bands are not only shown by $\left[\mathrm{M}(\text { bipy })_{3}\right]^{2+}$ with $\mathrm{M}=\mathrm{Fe}, \mathrm{Ru}$, and $\mathrm{Os}$ but also by the polynuclear complexes (bipy) $\left(\mathrm{H}_{2} \mathrm{O}\right) \mathrm{Pt}-\mu \mathrm{NC}$ $\mathrm{M}(\mathrm{CN})_{4}-\mu \mathrm{CN}-\mathrm{Pt}\left(\mathrm{H}_{2} \mathrm{O}\right)$ (bipy) [42]. In the latter case the $\mathrm{M} \rightarrow$ bipy MLCT transitions involve remote redox centers which are separated by the Pt-NC moiety.

Another large family of $\mathrm{d}^{6}$ complexes with MLCT absorptions which, however, appear in the UV region comprises cyano complexes [1] (e.g. $\left[\mathrm{M}(\mathrm{CN})_{6}\right]^{4-}$ with $\mathrm{M}=\mathrm{Fe}$, Ru and Os and metal carbonyls $[1,4,43]$ e.g. $\mathrm{M}(\mathrm{CO})_{6}$ with $\left.\mathrm{M}=\mathrm{Cr}, \mathrm{Mo}, \mathrm{W}\right)$. These MLCT bands may obscure less intense bands of different origin such as LF absorption. A characteristic long-wavelength MLCT band was also identified in the abs. spectrum of the carbene complex $\mathrm{Mn}\left(\mathrm{C}_{5} \mathrm{H}_{5}\right)(\mathrm{CO})_{2}\left(\mathrm{CPh}_{2}\right)\left(\lambda_{\max }=380 \mathrm{~nm}\right.$, Fig. 5) [44].

\subsection{2. $d^{8}$}

Generally, $\mathrm{d}^{8}$ complexes occur in square-planar or trigonal-bipyramidal structures. Reducing $\mathrm{d}^{8}$ metals include $\mathrm{Fe}(\mathrm{O}), \mathrm{Ru}(\mathrm{O}), \mathrm{Os}(\mathrm{O})$, and $\mathrm{Pt}(\mathrm{II}) . \mathrm{Pt}^{\mathrm{II}}$

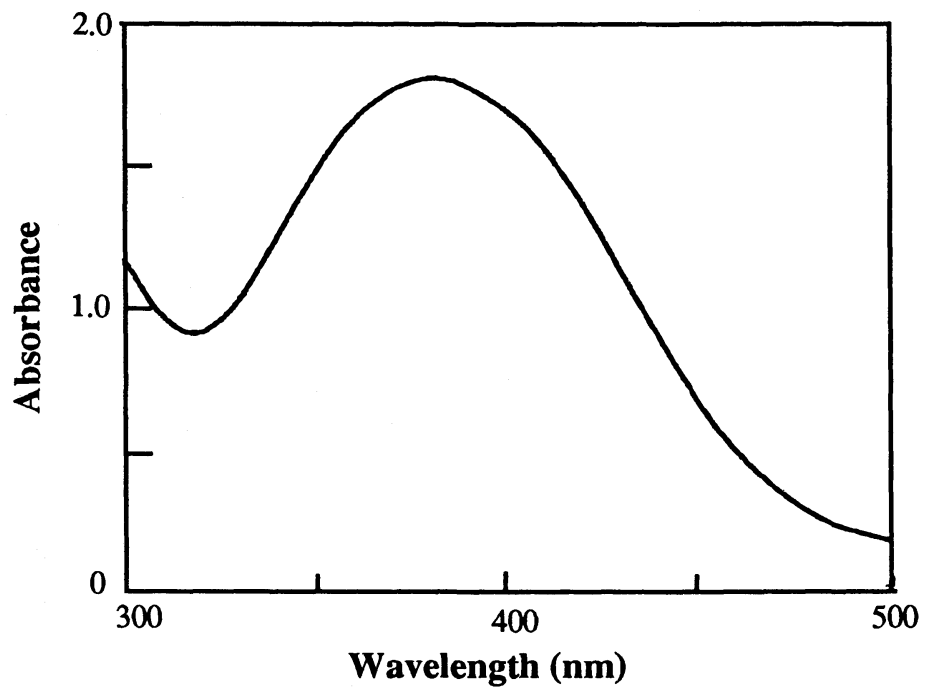

Figure 5 Electronic absorption spectrum of $2.15 \times 10^{-4} \mathrm{M} \eta^{5}-\left[\mathrm{C}_{5} \mathrm{H}_{5} \mathrm{Mn}(\mathrm{CO})_{2}-\mathrm{CPh}_{2}\right]$ in argon-saturated THF. 
polypyridyl (e.g. $\mathrm{Pt}$ (bipy) $\mathrm{Cl}_{2}$ in water, $\lambda_{\max }=340 \mathrm{~nm}$ ) [45] and olefin complexes (e.g. $\left[\mathrm{Pt}\left(\mathrm{C}_{2} \mathrm{H}_{4}\right) \mathrm{Cl}_{3}\right]^{-}, \lambda_{\max }=330 \mathrm{~nm}[46,47]$ ) display longwavelength MLCT absorptions. MLCT bands appear also in the spectra of $\mathrm{Fe}(\mathrm{CO})_{5}\left(\lambda_{\max }=240 \mathrm{~nm}\right)[48]$ and $\left[\mathrm{Os}(\mathrm{CPh})(\mathrm{CO})_{2}\left(\mathrm{PPh}_{3}\right)_{2}\right]^{+}\left(\lambda_{\max }=\right.$ $318 \mathrm{~nm}$ ) [49]. In the latter case the carbyne ligand provides $\pi^{*}$ orbitals at rather low energies.

\subsection{3. $d^{10}$}

In addition to CT bands ds (or dp) absorptions can appear in the spectra of $\mathrm{d}^{10}$ complexes. The spectrum of $\mathrm{Ni}(\mathrm{CO})_{4}$ is a case in question. Although it has been suggested that ds bands occur [4] it seems more likely that these absorptions are of the MLCT type [50,51]. The long wavelength absorption of the isoelectronic anion $\left[\mathrm{Fe}(\mathrm{CO})_{4}\right]^{2-}$ has been also assigned to a MLCT transition [52]. Well-documented are the MLCT spectra of $\mathrm{Cu}(\mathrm{I})$ complexes with polypyridyl [9] (e.g. [Cu(o-phen) $\left.\left(\mathrm{PPh}_{3}\right)_{2}\right]^{+}\left(\lambda_{\max }=365 \mathrm{~nm}\right.$ [53]) as well as those of $\mathrm{Au}(\mathrm{I})$ complexes such as as $\left[\mathrm{Au}(\mathrm{CN})_{2}\right]^{-}\left(\lambda_{\max }=240 \mathrm{~nm}\right.$ [54]).

\subsection{4. $s^{2}$}

Metal ions with an $\mathrm{s}^{2}$ configuration are frequently reducing (e.g. $\mathrm{Tl}^{+}, \mathrm{Sn}^{2+}$, $\left.\mathrm{Sb}^{3+}\right)$. Accordingly, long wavelength absorptions of the compounds $\mathrm{M}$ (bipy) $\mathrm{X}_{3}$ with $\mathrm{M}=\mathrm{Sb}, \mathrm{Bi}$ and $\mathrm{X}=\mathrm{Cl}, \mathrm{Br}$, I were assigned to MLCT transitions [55]. However, these compounds exist only as solids and complications by solid state effects can presently not be excluded.

\subsection{METAL-TO-METAL CHARGE TRANSFER (MMCT)}

Two different types of MMCT transitions can be distinguished. More familiar are those which occur in polynuclear complexes with bridging ligands between oxidizing and reducing metal centers $\left(\mathrm{M}_{\text {red }}-\mathrm{L}-\mathrm{M}_{\mathrm{ox}}\right)$ In addition, MMCT bands appear also in the spectra of polynuclear complexes with direct but polar metal-metal bonds $\left(\mathrm{M}_{\mathrm{red}}-\mathrm{M}_{\mathrm{ox}}\right)$.

\subsection{1- $M_{\text {red }}-L-M_{o x}$}

Our knowledge of MMCT spectra is largely based on observations on mixed-valence (MV) complexes [56-58] such as the Creutz-Taube ion 
$\left[\left(\mathrm{NH}_{3}\right)_{5} \mathrm{Ru} \text {-pyrazine- } \mathrm{Ru}\left(\mathrm{NH}_{3}\right)_{5}\right]^{5+}$ which formally contains $\mathrm{Ru}(\mathrm{II})$ and $\mathrm{Ru}$ (III) (see also Scandola's chapter). Since both metals are electronically coupled an electron delocalization takes place. With increasing metal-metal interaction the individual metal ions $\mathrm{Ru}^{2+}$ and $\mathrm{Ru}^{3+}$ lose their identity. Finally, the valence orbitals of both metals are completely delocalized and the metals no longer exist in well-defined ("trapped") oxidation states. Both ruthenium atoms now have the intermediate oxidation state 2.5 . While the localized MV complex is characterized by a $\mathrm{Ru}^{2+} \rightarrow \mathrm{Ru}^{3+} \mathrm{MMCT}$ transition little CT is associated with the "MMCT" transition of a delocalized MV complex.

Irrespective of the extent of delocalization most MV compounds are of limited interest to photochemists since they do not undergo a permanent chemical change upon MMCT excitation [59,60]. First of all, in a symmetrical MV complex an electron exchange between both metals does not cause a change of the chemical composition. In addition, the electron exchange occurs also thermally under ambient conditions. Finally, MMCT bands of symmetrical MV complexes usually appear in the near IR which is not easily accessible by conventional irradiation sources and light detection devices. Generally, these considerations do not apply to polynuclear complexes which contain different metals as redox centers [59,60]. Owing to the redox asymmetry MMCT bands are shifted to higher energies and a thermal electron exchange does not take place. Moreover, the metal centers are weakly coupled in heteronuclear complexes of this type. Such compounds which are often light sensitive will now be discussed briefly.

Polynuclear ligand-bridged complexes with weak metal-metal coupling may be viewed as being composed of mononuclear components which preserve their identity in the polynuclear compound. The electronic spectrum consists then of the superimposed spectra of these components. If reducing and oxidizing metals are present additional MMCT bands appear $[59,60]$. Their energy is the sum of the reorganizational energy and the redox asymmetry. The complex $\left[\left(\mathrm{NH}_{3}\right)_{5} \mathrm{Co}^{\mathrm{III}} \mathrm{NCRu}{ }^{\mathrm{II}}(\mathrm{CN})_{5}\right]^{-}$represents a typical example [61]. The absorption spectrum (Fig. 6) is composed of the spectra of the mononuclear constituents $\left[\mathrm{Co}\left(\mathrm{NH}_{3}\right)_{5} \mathrm{NC}\right]^{2+}$ and $\left[\mathrm{Ru}(\mathrm{CN})_{6}\right]^{4-}$. In addition, a RuII $\rightarrow$ Co ${ }^{I I I}$ MMCT absorption appears at $\lambda_{\max }=375 \mathrm{~nm}$. The reorganizational energy contributes considerably to this MMCT transition since it terminates in a $\sigma_{\mathrm{d}}{ }^{*}$ orbital which is strongly antibonding with regard to the cobalt-nitrogen bonds.

The occurrence of MMCT bands is not restricted to typical transition metals. The moiety $\mathrm{Hg}^{\mathrm{II}} \mathrm{NCFe}{ }^{\mathrm{II}}(\mathrm{CN})_{5}$ exhibits a Fe $\mathrm{II} \rightarrow \mathrm{Hg}^{\mathrm{II}} \mathrm{MMCT}$ band 


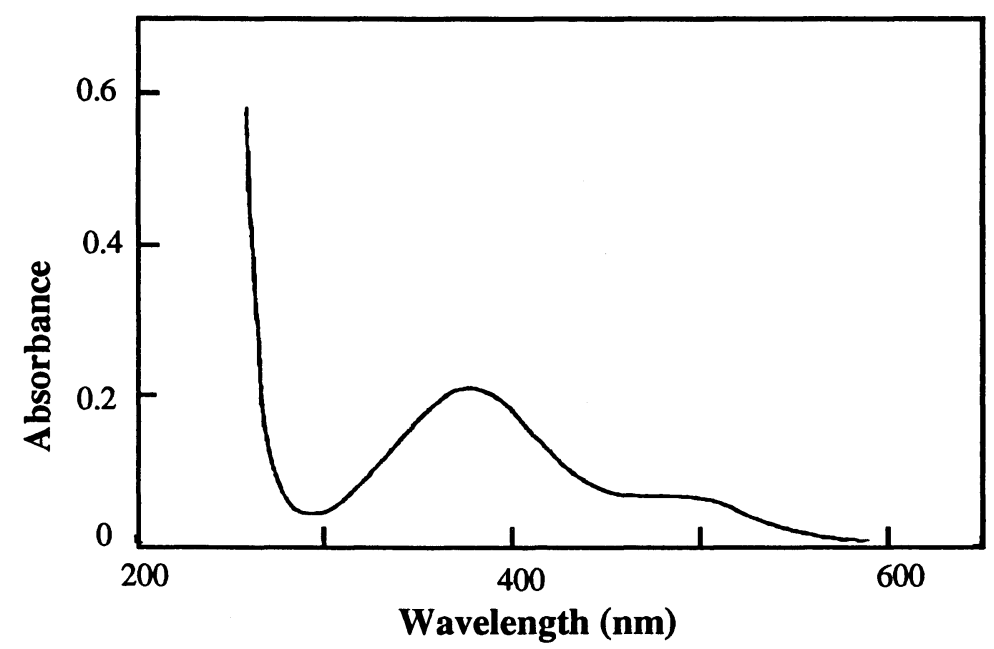

Figure 6 Electronic absorption spectrum of $3.0 \times 10^{-4} \mathrm{M} \mathrm{Na}\left[\left(\mathrm{NH}_{3}\right)_{5} \mathrm{Co}-\mathrm{NC}-\mathrm{Ru}(\mathrm{CN})_{5}\right]$ in $0.01 \mathrm{n} \mathrm{HClO}_{4}$

at $\lambda_{\max }=265 \mathrm{~nm}$ [62]. Even binuclear main group metal complexes have been observed to show MMCT absorptions. For example, the anion $\left[\mathrm{Sn}_{2} \mathrm{Cl}_{10}\right]^{4-}$ displays a $\mathrm{Sn}{ }^{\mathrm{II}} \rightarrow \mathrm{Sn}^{\mathrm{IV}} \mathrm{CT}$ absorption maximum near 340 $\mathrm{nm}[63]$.

\subsection{2. $M_{\text {red }}-M_{o x}$}

If a reducing and an oxidizing metal are not bridged by a ligand but are connected by a direct, but polar metal-metal bond MMCT bands may be also observed. Generally, polar metal-metal bonds are found in heteronuclear complexes which contain metals of different electronegativity. Metal-metal coupling is strong in this case and electron delocalization is only limited by the different energies of the overlapping metal orbitals. This type of polar metal-metal bond occurs in the complex $\mathrm{Ph}_{3} \mathrm{PAu}^{\mathrm{I}}-\mathrm{Co}^{\mathrm{I}}(\mathrm{CO})_{4}$ [64]. The absorption spectrum exhibits a low-energy $\mathrm{Co}(-\mathrm{I}) \rightarrow \mathrm{Au}(\mathrm{I}) \mathrm{MMCT}$ band. This MMCT transition involves the promotion of a metal-metal bonding electron to a $\sigma^{*}(\mathrm{M}-\mathrm{M})$ orbital. The complexes $\left[(\mathrm{NC})_{5} \mathrm{Co}_{0} \mathrm{I}_{-} \mathrm{Hg}^{\mathrm{II}}-\mathrm{Co}^{\mathrm{I}}(\mathrm{CN})_{5}\right]^{6-}$ $\left(\lambda_{\max }=361 \mathrm{~nm}\right.$, Fig. 7 [62] $)$ and $(\mathrm{OC})_{4} \mathrm{Co}^{-\mathrm{I}}-\mathrm{M}^{\mathrm{II}}-\mathrm{Co}^{-\mathrm{I}}(\mathrm{CO})_{4}[65]$ with $\mathrm{M}=$ $\mathrm{Zn}, \mathrm{Cd}$ and $\mathrm{Hg}$ are further examples which are characterized by such MMCT absorptions. In the latter case the $\mathrm{Co}(-\mathrm{I}) \rightarrow \mathrm{M}$ (II) MMCT bands undergo a blue shift from $\mathrm{Hg}\left(\lambda_{\max }=328 \mathrm{~nm}\right)$ to $\mathrm{Cd}(302 \mathrm{~nm})$ and $\mathrm{Zn}(284 \mathrm{~nm})$ since the energy of the ns acceptor orbitals of M(II) increases in this order. 


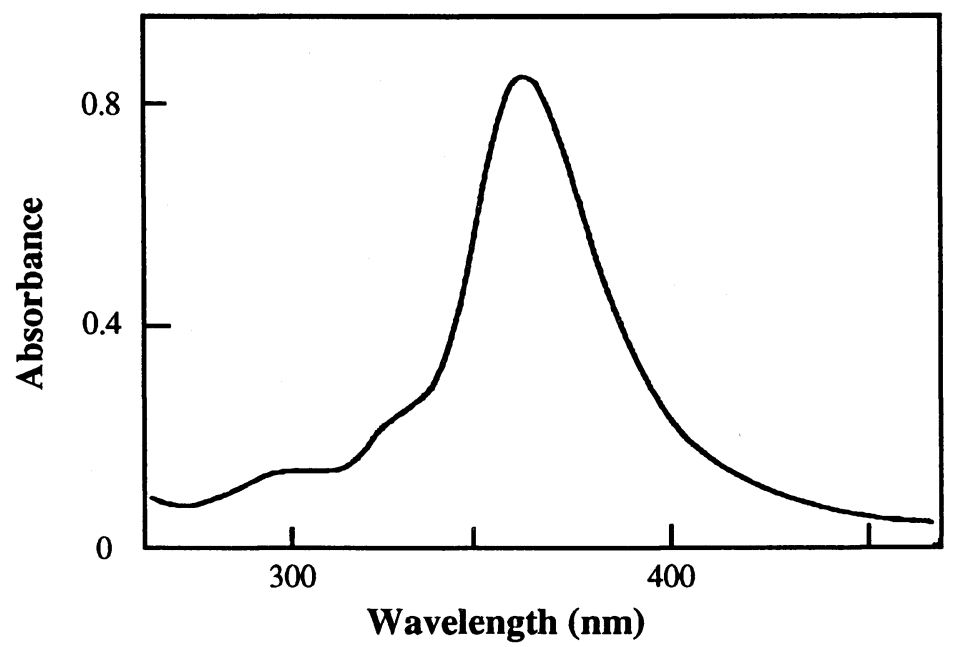

Figure 7 Electronic absorption spectrum of $1.58 \times 10^{-5} \mathrm{M} \mathrm{K}_{6}\left[\mathrm{HgCo}_{2}(\mathrm{CN})_{10}\right]$ in argonsaturated $0.1 \mathrm{M} \mathrm{NaOH}$.

\subsection{LIGAND-TO-LIGAND CHARGE TRANSFER (LLCT)}

Any mixed-ligand complex of the type $\mathrm{L}_{\mathrm{red}}-\mathrm{M}-\mathrm{L}_{\text {ox }}^{\prime}$ may display LLCT bands in its absorption spectrum [20]. In contrast to this expectation surprisingly little is known about it. Nevertheless, during recent years an increasing number of observations on LLCT has been reported. LLCT bands were identified in the absorption spectra of complexes which contain the following donor and acceptor ligands: Donors: $\mathrm{X}^{-}$(halides), $\mathrm{RS}^{-}$(thiolates), $\mathrm{R}^{-}$(carbanions) Acceptors: polypyridyls (e.g. bipy), porphyrins Some complexes which show LLCT absorptions are presented in Table $4[20,66]$. In most cases the band assignments are rather clear since other absorptions of different origin do not appear in the same energy region.

An interesting class of compounds which are characterized by longwavelength LLCT absorptions comprises ligand-based MV complexes [20].

Table 4 Halide-to-diimine LLCT absorptions $\left(\lambda_{\max }\right.$ in $\left.\mathrm{nm}\right)[20,66]$

\begin{tabular}{ll|ll}
\hline Complex & $\lambda_{\max }(\mathrm{nm})$ & Complex & $\lambda_{\max }(\mathrm{nm})$ \\
\hline $\mathrm{Be}(\mathrm{bipy}) \mathrm{Cl}_{2}$ & 352 & $\mathrm{Zn}($ bipy $)\left(\mathrm{C}_{2} \mathrm{H}_{5}\right)_{2}$ & 420 \\
$\mathrm{Be}(\mathrm{bipy}) \mathrm{Br}_{2}$ & 364 & {$\left[\mathrm{Tl}(\mathrm{bipy})_{2} \mathrm{l}_{2}\right]^{+}$} & 374 \\
$\left.\mathrm{Be}(\mathrm{bipy})\right|_{2}$ & 368 & $\operatorname{Re}(\mathrm{CO})_{3}\left(\mathrm{p}-\mathrm{Tol}_{2} \mathrm{DAB}\right) \mathrm{Br}^{\#}$ & 505 \\
\hline
\end{tabular}

\# $p$-Tol-DAB $=p$-tolyl-1,4-diaza-1,3-butadiene. 
These compounds contain the same ligand in two different redox states in analogy to metal-based MV complexes. Generally, the ligands are derived from quinones and the corresponding hydroquinones. LLCT involves an electronic transition from the hydroquinone donor to the quinone acceptor ligand. However, the electronic coupling of both ligands introduces a serious complication. Since the intervening metal mediates a strong ligandligand interaction they may exist in intermediate redox states (e.g. as semiquinones). A "LLCT" transition occurs then in a delocalized ligand system and does not involve any CT. Intense long-wavelength absorptions of this type appear in the electronic spectra of square-planar dithiolene complexes such as $\mathrm{M}^{\mathrm{II}}$ (dithiolene) ${ }_{2}$ with $\mathrm{M}=\mathrm{Ni}, \mathrm{Pd}$, and $\mathrm{Pt}[67,68]$.
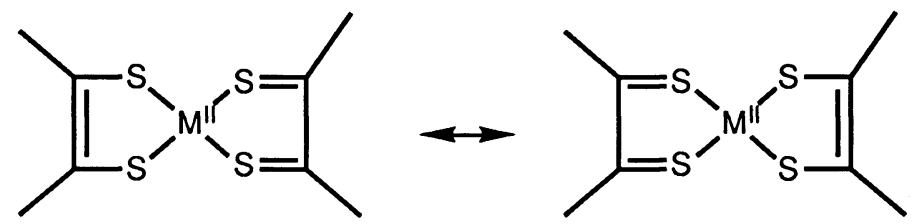

A chemical modification of the ligands leads to a redox asymmetry which reduces the delocalization and favors one resonance structure in the ground state $[20,69]$ :

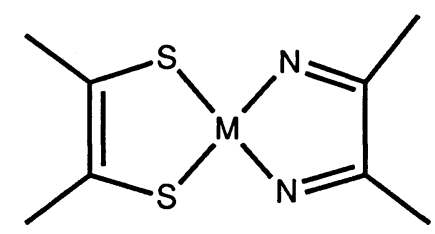

Such complexes which contain a 1,2-diimine (e.g. bipy) and a 1,2-dithiolate ligand exhibit a long-wavelength absorption. It belongs to a real (dithiolate to diimine) LLCT transition. Since the band position depends strongly on the polarity of the solvent the complexes are extremely solvatochromic. If $\mathrm{M}(\mathrm{II})$ is $\mathrm{Zn}^{2+}$ the complexes are tetrahedral. Due to the orthogonal orientation of the planes of both ligands the electronic coupling of the ligands is weak and the LLCT absorption is of low intensity (e.g. $\lambda_{\max }=$ $445 \mathrm{~nm}, \varepsilon=72$ for [Zn(bipy)(3,4-toluenedithiolate)], Fig. 8) [70].

\subsection{INTRA-LIGAND CHARGE TRANSFER (ILCT)}

A ligand itself may consist of a reducing and oxidizing part [20]. The spectrum of the metal complex should then show an ILCT band which 


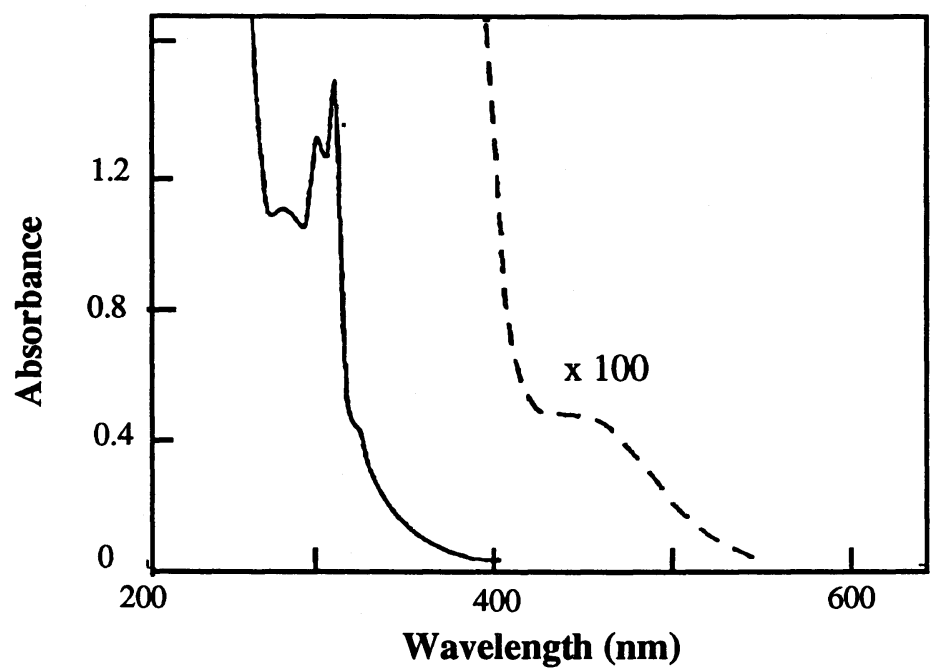

Figure 8 Electronic absorption spectrum of $7.54 \times 10^{-5} \mathrm{M}$ of $\mathrm{Zn}$ (bipy)(tdt) in $\mathrm{CH}_{2} \mathrm{Cl}_{2}$. (tdt = 3,4-toluenedithiolate).

belongs to an electronic transition from the donor to the acceptor site of the same ligand. Such an ILCT absorption appears in the spectrum of [biacetylbis(mercaptoethylimine)-nickel(II)] $\left(\lambda_{\max }=585 \mathrm{~nm}\right.$, in $\left.\mathrm{CCl}_{4}\right)$ [71].

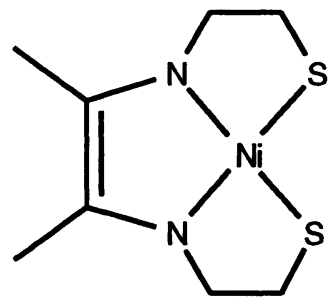

The donor site is the reducing thiolate moiety while the diimine is the accepting part of the chelate ligand. Such ILCT bands were also detected in the spectra of similar $\mathrm{Zn}$ (II) and $\mathrm{Ni}$ (II) complexes [72].

An interesting case of ILCT occurs in the complex $\left[\mathrm{Pt}^{\mathrm{II}}(\mathrm{l} \text {-naphthylamine })_{2} \mathrm{Cl}_{2}\right]$ [73]. Light absorption by the free naphthylamine leads to a shift of electron density from the nitrogen lone pair into the aromatic ring system. Ground and excited state are described by two limiting resonance structures. 


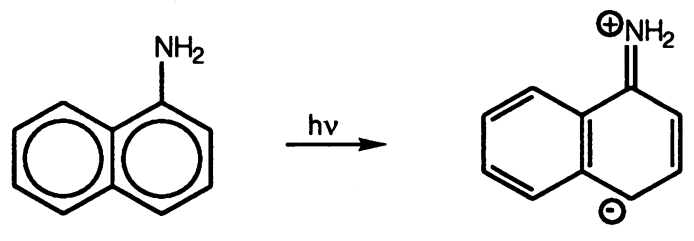

This electronic transition appears as an ILCT absorption of the platinum complex at $\lambda_{\max }=293 \mathrm{~nm}$.

\section{Emission from Charge Transfer States}

Luminescence spectroscopy is an indispensable tool for the characterization of excited states. Unfortunately, the majority of metal complexes is not emissive. Those complexes which are luminescent $[2-6,74,75]$ are mostly diamagnetic in the ground state. Generally, the emission originates from the energetically lowest triplet state. In the following discussion it is thus implied that the emission is a phosphorescence. Compared to most organic compounds the radiative lifetime of excited triplets of metal complexes is much shorter. Although the phosphorescence is spin-forbidden it becomes partially allowed by a rather strong spin-orbit coupling, particularly of the metals of the second and third transition row (heavy atom effect). In rare cases a fluorescence originating from the lowest-energy singlet is also observed. Irrespective of the spin multiplicity the luminescence of metal complexes may occur from all types of excited states including IL and MC states $[2-6,74,75]$. The emitting CT states are classified according to the labels which refer to the transitions in absorption.

\subsection{LMCT}

It seems to be surprising that only a few examples of luminescent LMCT states are known. This lack could have two explanations. Many complexes with prominent LMCT states have other excited states such as MC states at lower energies. These provide a facile access for radiationless deactivation of LMCT states. In other cases LMCT states are quite reactive and photoreactions compete successfully with the luminescence.

Molecular $\mathrm{d}^{0}$ oxo complexes of $\mathrm{MO}_{4}{ }^{\mathrm{n}-}$ which have low-energy LMCT states have not yet been observed to emit. However, some $\mathrm{d}^{0}$ oxometallates are known to luminesce in the solid state [76]. The organometallic $\mathrm{d}^{0}$ oxide $\mathrm{CH}_{3} \mathrm{ReO}_{3}$ emits $\left(\lambda_{\max }=640 \mathrm{~nm}\right)$ from the lowest LMCT state in low temperature glasses [22]. 
Complexes of $\mathrm{d}^{10}$ metals such as $\mathrm{Zn}^{2+}$ and $\mathrm{Cd}^{2+}$ may be also expected to exhibit a luminescence from LMCT states since semiconductors such as $\mathrm{ZnO}, \mathrm{ZnS}$, and $\mathrm{CdS}$ undergo a band gap emission which corresponds to the luminescence from LMCT states. Contrary to this expectation simple $\mathrm{Zn}^{2+}$ and $\mathrm{Cd}^{2+}$ complexes have not been observed to emit. However, polynuclear complexes of these metals have been reported to luminesce from LMCT states. While the emission of $\left.\left[\mathrm{Zn}_{4} \mathrm{O} \text { (acetate }\right)_{6}\right]\left(\lambda_{\max }=372 \mathrm{~nm}\right)$ [77] is quite strong the clusters $\left[\mathrm{M}_{4}(\mathrm{SPh}) 10^{\mathrm{l}^{2-}}\right.$ with $\mathrm{M}=\mathrm{Zn}^{2+}\left(\lambda_{\max }=360 \mathrm{~nm}\right)[78]$ and $\mathrm{Cd}^{2+}\left(\lambda_{\max }=500 \mathrm{~nm}\right)$ [79] are weak emitters due to competing photoreactions. $\left[\mathrm{Ru}(\mathrm{CN})_{6}\right]^{3-}\left(\lambda_{\max }=525 \mathrm{~nm}\right)[80]$ and $\left[\mathrm{UO}_{2}\right]^{2+}\left(\right.$ in $\mathrm{HClO}_{4}$ $\lambda_{\max }=509 \mathrm{~nm}$ ) [34] undergo also an emission from LMCT states. The strong luminescence of the uranyl cation has been investigated in all details [35].

\subsection{MLCT}

The largest family of luminescent metal compounds comprises those complexes which emit from MLCT states. This emission is facilitated by the fact that generally MLCT excitation has only a small effect on the metalligand bonding and does not initiate competing unimolecular photoreactions. Intense luminescence can thus be observed under ambient conditions. The most prominent emitters include $\left.\left[\mathrm{Ru}^{\mathrm{II}} \text { (bipy) }\right]_{3}\right]^{2+}[41,81]$ and $\mathrm{Re}(0-$ phen $)(\mathrm{CO})_{3} \mathrm{Cl}[4,75]$ and their derivatives. Any discussion of these complexes is omitted here since they are treated elsewhere in this book.

Other organometallic compounds such as substituted hexacarbonyls [75], carbyne (e.g. $\mathrm{W}(\mathrm{CO})_{2}$ (diphos) $(\mathrm{CPh}) \mathrm{Cl}\left(\lambda_{\max }=639 \mathrm{~nm}\right)$ [82], isocyanide (e.g. $\mathrm{W}(\mathrm{CNPh})_{6}\left(\lambda_{\max }=638 \mathrm{~nm}\right.$ [83] and orthometalated complexes (e.g. Pt(thpy) ${ }_{2}$ with thpy ${ }^{-}=2-\left(2\right.$-thienyl)pyridine anion, $\left(\lambda_{\max }=580 \mathrm{~nm}\right)$ [84-86] are further examples of luminescent MLCT states.

\subsection{MMCT}

MMCT states are usually not emissive since the thermally equilibrated states are too low in energy $[59,60]$. In many cases MMCT states can be considered to be redox isomers with energies slightly higher than that of the ground state. Nevertheless, some compounds have been reported to show a MMCT emission in the solid state $[39,76 \mathrm{~b}]$. For example, if $\mathrm{Cs}_{2} \mathrm{ZrCl}_{6}$ is doped with $\mathrm{Pb}^{2+}$ a red luminescence appears which originates from a $\mathrm{Pb}(\mathrm{II}) \rightarrow \mathrm{Zr}(\mathrm{IV}) \mathrm{MMCT}$ excited state. 


\subsection{LLCT}

A few complexes are known to emit from LLCT states. [PII (bipy)(toluenedithiolate)] shows a LLCT luminescence at $\lambda_{\max }=654$ $\mathrm{nm}$ at $77 \mathrm{~K}$ [87]. Zinc(II) and cadmium(II) compounds of the type [M(1,2-diimine $\left.)(\mathrm{SR})_{2}\right]$ have been also observed to luminesce from LLCT states [88]. The complex [Os $\left.{ }^{\mathrm{II}}(\mathrm{bipy})_{2}(\mathrm{CO})(\mathrm{DMABN})\right]^{2+}$ with the donor ligand 4-(N,N-dimethylamino)benzonitrile (DMABN) has available a DMABN $\rightarrow$ bipy LLCT state which is populated by intramolecular electron transfer from a MLCT excited state and deactivated by emission [89].

\section{Charge Transfer Excitation}

The generation of CT excited metal complexes can take place by a variety of processes. Most common is the direct optical excitation by light absorption into a CT band. CT states may, however, be also populated by radiationless deactivation from other excited states at higher energies. This process can be viewed as an intramolecular energy transfer.

Intramolecular excited state electron transfer provides a further possibility to obtain excited CT states. Complexes of the type $\left[\mathrm{Co}^{\mathrm{III}}\left(\mathrm{NH}_{3}\right)_{5} \mathrm{O}_{2} \mathrm{CR}\right]^{2+}$ with $R=$ stilbene $[60,90,91]$ and naphthalene $[60,92]$ may be taken as examples. The aromatic group $\mathrm{R}$ is an electron donor while $\mathrm{Co}$ (III) serves as acceptor. However, owing to the insulating effect of the coordinating carboxylic substituent, $\mathrm{R}$ and $\mathrm{Co}$ (III) are not coupled electronically. Accordingly, a $\mathrm{R} \rightarrow \mathrm{Co}(\mathrm{III}) \mathrm{LMCT}$ absorption does not appear and $\mathrm{R}$ exists as an isolated chromophore of the complex. Upon light absorption by $\mathrm{R} a$ $\pi \pi^{*} \mathrm{IL}$ state is obtained which is strongly reducing and transfers an electron to $\mathrm{Co}$ (III). The resulting electron distribution $\left[\mathrm{Co}^{\mathrm{II}}\left(\mathrm{NH}_{3}\right)_{5} \mathrm{O}_{2} \mathrm{C}-\mathrm{R}^{+}\right]^{2+}$ is nothing else but a LMCT state which cannot be reached directly by light absorption. By quite the same mechanism other CT excited states may be generated, too. For example, $\left[\operatorname{Re}^{\mathrm{I}}\left(\mathrm{bipy}^{-}\right)(\mathrm{CO})_{3}(\mathrm{py}-\mathrm{PTZ})\right]^{+}$contains a coordinated pyridine (py) which is linked at its 4 position to the reducing phenothiazine (PTZ) via a methylene group [93]. A PTZ $\rightarrow$ bipy LLCT absorption does not appear due to the weak coupling between donor and acceptor. Light absorption by a MLCT band leads to the excited state $\left[\operatorname{Re}^{I I}\left(\text { bipy }^{-}\right)(C O)_{3}(\text { py-PTZ })\right]^{+}$which undergoes a rapid excited state electron transfer from PTZ to the oxidized Re center. The result of this excited state electron transfer is a LLCT state with the electron distribution 
$\left[\operatorname{Re}^{\mathrm{I}}\left(\text { bipy }^{-}\right)(\mathrm{CO})_{3}\left(\mathrm{py}-\mathrm{PTZ}^{+}\right)\right]^{+}$. It returns to the ground state with a rate constant $\mathrm{k}=4 \times 10^{8} \mathrm{~s}^{-1}$ [93].

Of course, CT excited states can be also generated by intermolecular energy and electron transfer processes which are discussed in other chapters of this book.

\section{Reactivity of Charge Transfer States}

As any electronically excited compound CT excited complexes are also strong reductants and oxidants which are able to participate in intermolecular electron transfer reactions. These processes are treated elsewhere in this book. In addition to intermolecular electron transfer CT excited complexes can undergo a variety of different photoreactions. In many cases the photoproducts reflect the electron distribution in the CT state. The products are then obtained directly by photochemical redox processes. In other cases such a simple relationship is not apparent. For example, a CT excited complex may become kinetically labile and undergoes a ligand substitution before a charge recombination regenerates the electron distribution of the ground state. As a result a ligand exchange is induced by CT excitation. As another possibility the electron distribution of a CT state could facilitate an electrophilic or nucleophilic attack of a suitable reagent at the metal or the ligand. Again, a connection between the nature of the CT state and the type of photoproduct may not be recognized immediately.

\subsection{LMCT}

In a LMCT state the metal is reduced and a ligand oxidized. This electron distribution determines the reactivity of LMCT states. Co(III) complexes are best suited to illustrate the photochemistry induced by LMCT excitation since these compounds have been studied extensively and a variety of different photoreactions have been identified $[2,5,94]$.

\subsubsection{Cobalt(III) complexes}

Light absorption by (X to Co(III)) LMCT bands of octahedral low-spin $\mathrm{Co}$ (III) complexes $\mathrm{CoL}_{5} \mathrm{X}$ is associated with the transfer of a ligand electron into the Co-ligand antibonding e orbitals. This excitation induces a homolytic cleavage of the $\mathrm{Co}-\mathrm{X}$ bond yielding a reduced complex fragment $\mathrm{Co}{ }^{I} L_{5}$ and an oxidized ligand radical $\mathrm{X} \cdot$ : 


$$
\mathrm{Co}^{\mathrm{III}} \mathrm{L}_{5} \mathrm{X} \quad \rightarrow \quad\left[\mathrm{Co} \mathrm{II}_{L_{5}} / \cdot \mathrm{X}\right]
$$

The identity and reactivity of this primary product have been interpreted by various models. Only a few important features will be outlined at this point. The radical pair $\mathrm{Co}^{\mathrm{II}} \mathrm{L} / \mathrm{X}$. is assumed to be formed in a cage of solvent molecules. Geminate recombination leads back to the starting complex.

$$
\left[\mathrm{Co}^{\mathrm{II}} \mathrm{L}_{5} / \cdot \mathrm{X}\right] \quad \rightarrow \quad \mathrm{Co}^{\mathrm{III}_{\mathrm{L}} \mathrm{X}}
$$

Cage escape to the solvent-separated radical pair opens further reaction channels such as secondary recombination and other reactions.

$$
\mathrm{Co}^{\mathrm{II}} \mathrm{L}_{5} / \mathrm{X} \cdot \rightarrow \mathrm{Co}^{\mathrm{II}} \mathrm{L}_{5}+\mathrm{X} \cdot \overbrace{\text { product formation }}^{\mathrm{Co}^{\mathrm{II}} \mathrm{L}_{5} \mathrm{X}}
$$

For the product formation a variety of possibilities exists. If the complex fragment or the ligand radical undergo a rapid irreversible reaction stable photoredox products are obtained. For example, the complex fragment $\mathrm{Co}\left(\mathrm{NH}_{3}\right)_{5}{ }^{2+}$ in water decays to $\mathrm{Co}\left(\mathrm{H}_{2} \mathrm{O}\right)_{6}{ }^{2+}$ and ammonia with $\mathrm{k}>10^{6} \mathrm{~s}^{-1}$ [95]. Accordingly, the photoredox decomposition of $\mathrm{Co}(\mathrm{III})$ pentaammine complexes proceeds by equation (4) $(\mathrm{X}=$ halogen)

$$
\mathrm{Co} I I I\left(\mathrm{NH}_{3}\right)_{5} \mathrm{X}^{2+} \rightarrow \mathrm{Co}^{\mathrm{II}}\left(\mathrm{H}_{2} \mathrm{O}\right)_{6}{ }^{2+}+5 \mathrm{NH}_{3}+1 / 2 \mathrm{X}_{2}
$$

In the case of $\mathrm{Co}^{\mathrm{III}}(\mathrm{CN})_{5} \mathrm{X}^{3-}$ such a photoredox decomposition is not expected to take place since the primary complex fragment $\mathrm{Co}^{\mathrm{II}}(\mathrm{CN}) 5^{3-}$ does not decay but undergoes a recombination with $\mathrm{X} \cdot\left(\right.$ or $\left.\mathrm{X}_{2}\right)$ [94]. However, if the ligand radical reacts rapidly and irreversibly $\mathrm{Co}(\mathrm{CN})_{5} \mathrm{X}^{3-}$ will also yield stable photoredox products, e.g. $(\mathrm{X}=$ benzyl) [96]:

$$
\mathrm{Co}^{\mathrm{III}}(\mathrm{CN})_{5}\left(\mathrm{CH}_{2} \mathrm{Ph}\right)^{3-} \rightarrow \mathrm{Co}^{\mathrm{II}}(\mathrm{CN})_{5}^{3-}+1 / 2 \text { dibenzyl }
$$

In this case the radical coupling of the benzyl radicals competes apparently successfully with the recombination. Co(III) complexes with multidentate ligands which prevent also a facile decay of $\mathrm{Co}$ (II) complexes show similar photoproperties [94]. An important example for this behavior is methylcobalamin [4].

LMCT excitation of Co(III) complexes may not only yield photoredox products. Depending on the particular complex and reaction conditions other products are formed in addition or as an alternative. If ligands such as $\mathrm{NO}_{2}{ }^{2-}$ or NCS- have ambidentate character the recombination of the radical pair can lead to a linkage isomerization [5,54,97-99].

$$
\left[\mathrm{Co} I I I\left(\mathrm{NH}_{3}\right)_{5} \mathrm{NO}_{2}\right]^{2+} \rightarrow\left[\mathrm{Co}{ }^{\mathrm{III}}\left(\mathrm{NH}_{3}\right)_{5} \mathrm{ONO}\right]^{2+} \quad[\text { ref.97,98] }
$$


The restoration of Co(III) does not only take place by recombination but also by back electron transfer in the solvent-separated radical pair. This process yields a substituted complex.

$$
\left[\mathrm{Co} I I I\left(\mathrm{NH}_{3}\right)_{5} \mathrm{X}\right]^{2+}+\mathrm{H}_{2} \mathrm{O} \rightarrow \quad\left[\mathrm{Co}{ }^{\mathrm{III}}\left(\mathrm{NH}_{3}\right)_{5} \mathrm{H}_{2} \mathrm{O}\right]^{3+}+\mathrm{X}^{-}
$$

Insertion reactions or fragmentations of the separated radical pair might precede the back electron transfer. Such processes lead to a further variation of the photoproducts.

Insertion or addition $[96,100]$

$$
\begin{aligned}
& {\left[\mathrm{Co}{ }^{\mathrm{III}}(\mathrm{CN})_{5} \mathrm{CH}_{2}-\mathrm{Ph}\right]^{2+}+\mathrm{O}_{2} \rightarrow \mathrm{Co}^{\mathrm{III}}(\mathrm{CN})_{5} \mathrm{O}_{2}-\mathrm{CH}_{2}-\mathrm{Ph}} \\
& \mathrm{Co}^{\mathrm{III}}(\mathrm{CN})_{5} \mathrm{O}_{2}-\mathrm{CH}_{2}-\mathrm{Ph} \quad \mathrm{H}_{2} \mathrm{O} \\
& {\left[\mathrm{Co}^{\mathrm{III}}(\mathrm{CN})_{5} \mathrm{H}_{2} \mathrm{O}\right]^{2--}+\mathrm{OH}^{-}+\mathrm{Ph}-\mathrm{CHO}} \\
& \mathrm{Co} \text { III- } \mathrm{CH}_{3} \text { (methylcobalamin) }+\mathrm{CO} \rightarrow \mathrm{Co}-\mathrm{COCH}_{3}
\end{aligned}
$$

Fragmentation or elimination [101]

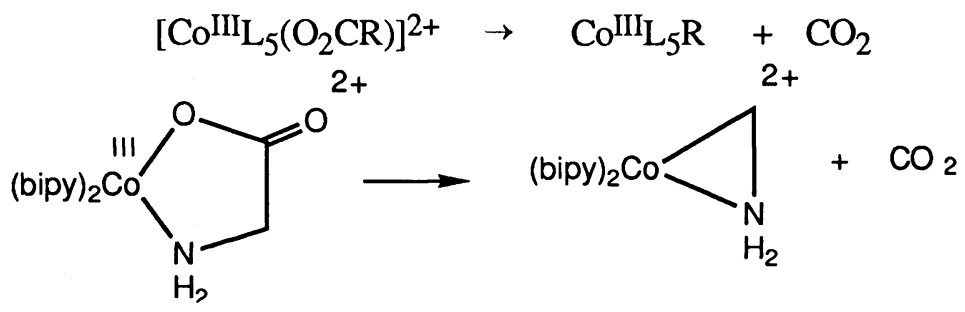

These reactions may take place exclusively or in competition with other reaction modes depending on the particular system.

\subsubsection{Other complexes}

While Co(III) compounds are well suited to outline some basic features of the reactivity of LMCT states important variations and extensions have been observed with other complexes.

\subsubsection{1. $\mathrm{d}^{5}$}

Since LMCT transitions of Co(III) complexes terminate at metal-ligand antibonding $\sigma$ orbitals the excited states are dissociative and quantum yields may be rather high. If the acceptor orbital at the metal has only a small influence on the metal-ligand bonding the photolysis is expected to be less 
efficient. Octahedral low-spin $\mathrm{d}^{5}$ complexes are suitable examples because low-energy LMCT transitions lead to the population of $d_{\pi}$ orbitals which are essentially non-bonding. $\mathrm{Cr}(\mathrm{CO})_{5} \mathrm{I}$ undergoes a photoredox reaction

$$
\mathrm{Cr}^{\mathrm{I}}(\mathrm{CO})_{5} \mathrm{I}+\mathrm{CH}_{3} \mathrm{CN} \rightarrow \mathrm{Cr}^{0}(\mathrm{CO})_{5} \mathrm{CH}_{3} \mathrm{CN}+1 / 2 \mathrm{I}_{2}
$$

However, the quantum yield of this photolysis is quite low $(\phi=0.01)$ [25]. Other $\mathrm{d}^{5}$ complexes such as $\left[\mathrm{Ru}\left(\mathrm{NH}_{3}\right)_{5} \mathrm{Cl}\right]^{2+}$ are also not very reactive upon LMCT excitation $[10,102]$.

\subsubsection{2. $\mathrm{d}^{0}$}

A large family of complexes with lowest-energy LMCT states comprises $\mathrm{d}^{0}$ complexes, in particular tetrahedral anions with oxide and sulfide ligands. Although many complexes of this type such as $\mathrm{MnO}_{4}^{-}$[103] and $\mathrm{MS}_{4}{ }^{\mathrm{n}}$ [104] with $M=V(V), M o(V I), W(V I)$, and $\operatorname{Re}(V I I)$ are light sensitive the mechanism of the photolysis is quite complicated. An interesting derivative of such compounds is the organometallic oxide $\mathrm{CH}_{3} \mathrm{Re}^{\mathrm{VII}} \mathrm{O}_{3}$ which photolyzes according to a simple pattern [22]. The lowest-energy transition involves the promotion of a $\mathrm{CH}_{3}-\mathrm{Re} \sigma$-bonding electron into a $\mathrm{Re}-\mathrm{O}$ antibonding $\pi$-orbital. Light absorption by the corresponding LMCT band generates the radical pair $\mathrm{CH}_{3} / \mathrm{ReO}_{3}$. The fate of this primary product is determined by the reactivity of the methyl radicals which attack the solvent by atom abstraction. In aqueous solution the photolysis yields only methane and perrhenic acid (equation 13):

$$
\mathrm{CH}_{3} \mathrm{ReO}_{3}+\mathrm{H}_{2} \mathrm{O} \rightarrow \mathrm{CH}_{4}+\mathrm{HReO}_{4}
$$

\subsubsection{Azide as ligand}

The photolysis of azide complexes induced by LMCT excitation leads to a variety of products depending on the specific complex and reaction conditions. The azide radical which is formed in the primary photochemical step is known to be very labile [105]. It eliminates nitrogen. The nitrogen atoms which are thus formed can be detected by ESR spectroscopy at low temperatures. In simple cases the photolysis of azide complexes yields only the reduced metal and molecular nitrogen, e.g., equation (14):

$$
\left[\mathrm{Au}^{\mathrm{I}}\left(\mathrm{N}_{3}\right)_{2}\right]^{-} \rightarrow \mathrm{Au}^{0}+1.5 \mathrm{~N}_{2}+\mathrm{N}_{3}^{-} \quad \text { [ref. 106] }
$$

In other cases the ejection of nitrogen is associated with the formation of nitrene intermediates (equation 15): 


$$
\mathrm{M}-\mathrm{N}_{3} \rightarrow \mathrm{M}-\mathrm{N}+\mathrm{N}_{2} \quad \text { [ref. 107-109] }
$$

This process is apparently favored if the LMCT states occur at rather high energies comparable to those of the azide IL states which contribute then to the photoactivity [110]. The nitrene complexes are not stable but add suitable substrates (equations 16, 17):

$$
\begin{gathered}
{\left[\mathrm{Rh}^{\mathrm{III}}\left(\mathrm{NH}_{3}\right)_{5} \mathrm{~N}_{3}\right]^{2+}+2 \mathrm{H}^{+}+\mathrm{Cl}^{-} \rightarrow} \\
{\left[\mathrm{Rh}^{\mathrm{III}}\left(\mathrm{NH}_{3}\right)_{5} \mathrm{NH}_{2} \mathrm{Cl}\right]^{3+}+\mathrm{N}_{2} \quad \text { [ref. 107,108] }} \\
{\left[\mathrm{W}^{0}(\mathrm{CO})_{5} \mathrm{~N}_{3}\right]^{-}+\mathrm{CO} \rightarrow\left[\mathrm{W}^{0}(\mathrm{CO})_{5} \mathrm{NCO}^{-}+\mathrm{N}_{2}\right. \text { [ref. 109] }}
\end{gathered}
$$

The ejection of $\mathrm{N}$ can be also followed by internal redox processes which lead to an oxidation of the metal and reduction of nitrogen to nitride [101].

$$
\mathrm{Cr}^{\mathrm{III}} \mathrm{L}_{5}\left(\mathrm{~N}_{3}\right)^{2+} \rightarrow \mathrm{Cr}^{2+} \mathrm{L}_{5} \mathrm{~N}^{2+}+\mathrm{N}_{2}
$$

\subsubsection{Reductive eliminations}

As a one-electron process optical LMCT excitation is assumed to yield a radical pair in the primary photochemical step. A further reduction of the metal can occur if the next stable oxidation state is lower by two units compared to the starting complex. Finally, the metal undergoes a $2 \mathrm{e}^{-}$-reduction while two ligands are cleaved off, each by a $1 \mathrm{e}^{-}$-oxidation (e.g. equation 19):

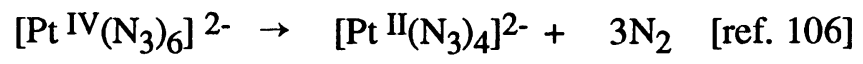

The mechanism of these reductive eliminations is of considerable interest. In some cases the overall photoreaction takes place in two consecutive le-transfer steps. The photolysis of several $\mathrm{Pt}(\mathrm{IV})$ complexes such as $\left.[\mathrm{PtX}]_{6}\right]^{2-}$ with $\mathrm{X}=$ halogen yields $\mathrm{Pt}(\mathrm{III})$ intermediates which were detected by ESR spectroscopy [111] and flash photolysis [112,113].

However, it is also feasible that Pt(III) does not represent an energy minimum for the transformation from $\mathrm{Pt}(\mathrm{IV})$ to $\mathrm{Pt}(\mathrm{II})$ [114]. Two ligand radicals must then be cleaved off in a concerted fashion. $\left[\mathrm{Pt}(\mathrm{CN})_{4}\left(\mathrm{~N}_{3}\right)_{2}\right]^{2-}$ seems to photolyze according to this mechanism [115].

$$
\left[\mathrm{Pt} I \mathrm{C}(\mathrm{CN})_{4}\left(\mathrm{~N}_{3}\right)_{2}\right]^{2-} \rightarrow \quad\left[\mathrm{Pt}^{\mathrm{II}}(\mathrm{CN})_{4}\right]^{2-}+2 \cdot \mathrm{N}_{3}
$$

Photochemical reductive eliminations induced by LMCT excitation were observed for a variety of different electron configurations at the metal. The versatility of this reaction is illustrated by a few examples. 
$\mathrm{d}^{6} \rightarrow \mathrm{d}^{8}:$

$\left[\mathrm{Pt}^{\mathrm{IV}}(\mathrm{CN})_{4} \mathrm{X}_{2}\right]^{2-} \rightarrow\left[\mathrm{Pt}^{\mathrm{II}}(\mathrm{CN})_{4}\right]^{2-}+2 \mathrm{X}(\mathrm{X}=\mathrm{Cl}, \mathrm{Br})[$ ref. 114] (21) The halogen atoms are scavenged by ethanol.

$\mathrm{d}^{8} \rightarrow \mathrm{d}^{10}:$

$\left[\mathrm{Pt}^{\mathrm{II}}\left(\mathrm{N}_{3}\right)_{4}\right]^{2-} \rightarrow \mathrm{Pt}^{0}+3 \mathrm{~N}_{2}+2 \mathrm{~N}_{3}^{-}$[ref. 106]

$\mathrm{Pt}^{\mathrm{II}}\left(\mathrm{PR}_{3}\right)\left(\mathrm{C}_{2} \mathrm{O}_{4}\right) \rightarrow \mathrm{Pt}^{0}\left(\mathrm{PR}_{3}\right)_{2}+2 \mathrm{CO}_{2}$ [ref. 116-118] (23)

$s^{0}\left(d^{10}\right) \rightarrow s^{2}:$

$\left[\mathrm{HgII}^{\mathrm{II}}\left(\mathrm{N}_{3}\right)_{3}\right]^{-} \rightarrow \mathrm{Hg}^{0}+3 \mathrm{~N}_{2}+\mathrm{N}_{3}^{-} \quad$ [ref. 27]

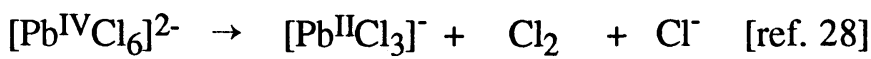

$s^{2} \rightarrow s^{2} p^{2}$

$\left[\mathrm{Te}^{\mathrm{IV}} \mathrm{Br}_{6}\right]^{2-} \rightarrow\left[\mathrm{TeBr}_{4}\right]^{2-}+\mathrm{Br}_{2} \quad$ [ref. 119]

$\mathrm{p}^{2} \rightarrow \mathrm{p}^{4}:$

$$
\left[\mathrm{IIII}^{\mathrm{IIC}}\right]_{4}^{-} \rightarrow\left[\mathrm{ICl}_{2}\right]^{-}+\mathrm{Cl}_{2} \quad \text { [ref. 120] }
$$

\subsection{MLCT}

Compared to LMCT states it is more difficult to anticipate the reactivity of MLCT states. First of all, most ligands are themselves electron-rich and cannot be reduced to stable species. Consequently, radical pairs (reversed to those formed from LMCT states) are certainly not generated. Nevertheless, a variety of reaction modes induced by MLCT excitation has been observed.

\subsubsection{Formation of solvated electrons / reduction of the solvent}

Since ligands are directly exposed to the solvent it is not surprising that electrons which reside in high-energy ligand orbitals can be ejected to the solvent. The formation of solvated electrons is thus a typical reaction of MLCT states. In some cases this reaction seems to be induced by CTTS (charge transfer to solvent) excitation $[6,37,38,121]$. However, CTTS absorptions are often difficult to identify and to distinguish from other bands. In any case, the formation of solvated electrons can be frequently related to the presence of MLCT states. Solvated electrons are detected by ESR or visible spectroscopy. They are stable in low-temperature matrices 
but appear only as transients in most solvents at room temperature. Since this subject has been extensively covered in several reviews $[6,37,38,121]$ only a few examples are mentioned here. A variety of reducing cyano complexes are known to photogenerate solvated electrons [122-124], e.g., reaction 28:

$$
\left[\mathrm{Fe}^{\mathrm{II}}(\mathrm{CN})_{6}\right]^{4-} \rightarrow\left[\mathrm{Fe}^{\mathrm{III}}(\mathrm{CN})_{6}\right]^{3-}+\mathrm{e}^{-}
$$

Recently, this photoreaction was also observed for a metal carbonyl anion.

$$
\left[\mathrm{Fe}^{-\mathrm{II}}(\mathrm{CO})_{4}\right]^{2-} \rightarrow\left[\mathrm{Fe}^{-\mathrm{I}}(\mathrm{CO})_{4}\right]^{-}+\mathrm{e}^{-} \quad \text { [ref. 52] }
$$

The generation of solvated electrons is followed by secondary processes including back electron transfer. Some solvents such as chlorinated hydrocarbons are reduced irreversibly.

$$
\begin{aligned}
& {\left[\mathrm{Ru}^{\mathrm{II}}(\mathrm{CN})_{6}\right]^{4-}+\mathrm{CHCl}_{3} \rightarrow} \\
& {\left[\mathrm{Ru}^{\mathrm{III}}(\mathrm{CN})_{6}\right]^{3-}+\mathrm{Cl}+\mathrm{CHCl}_{2} \quad \text { [ref. 125] }}
\end{aligned}
$$

Such photooxidations are also initiated by MLCT states of carbyne complexes.

$$
\begin{aligned}
& \mathrm{W}\left(\mathrm{C}_{5} \mathrm{H}_{5}\right)\left[\mathrm{P}(\mathrm{OMe})_{3}\right](\mathrm{CO})(\mathrm{CMe})+\mathrm{CHCl}_{3} \rightarrow \\
& \mathrm{W}\left(\mathrm{C}_{5} \mathrm{H}_{5}\right)\left[\mathrm{P}(\mathrm{OMe})_{3}(\mathrm{CO})(\mathrm{CMe})^{+}+\mathrm{Cl}^{-}+\mathrm{CHCl}_{2}\right. \text { [ref. 126] (31) }
\end{aligned}
$$

If the metal can be oxidized by two units photochemical oxidative additions may take place,. e.g., equations $(32,33)$ :

$$
\begin{aligned}
\mathrm{Pt}^{\mathrm{II}} \text { (bipy)Cl } \mathrm{Cl}_{2} & +\mathrm{CHCl}_{3} \rightarrow \mathrm{Pt}^{\mathrm{IV}}(\text { bipy }) \mathrm{Cl}_{4}+\mathrm{CHCl} \text { [ref.127] (32) } \\
\left.\mathrm{Pt}^{\mathrm{II}} \text { (thpy) }\right)_{2} & \left.+\mathrm{CHCl}_{3} \rightarrow \mathrm{Pt}^{\mathrm{IV}_{(}} \text {(thpy) }\right)_{2} \mathrm{Cl}\left(\mathrm{CHCl}_{2}\right) \\
& \text { (thpy }{ }^{-}=2 \text {-(2-thienyl)pyridine anion) }
\end{aligned}
$$

\subsubsection{Metal oxidation and ligand reduction}

Although ligands are usually not reduced to stable species a ligand reduction may occur in exceptional cases. MLCT excitation can thus lead to the oxidation of the metal and reduction of the ligand. Intramolecular photoredox processes of this type are well known, e.g., equation (34):

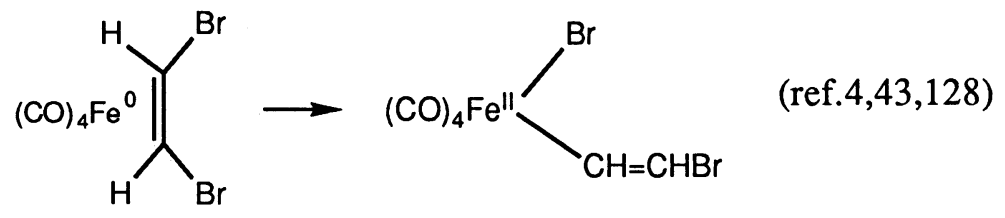


In suitable cases the charge distribution in the MLCT state is stabilized by intermolecular addition reactions., e.g., equation (35):

$$
\begin{aligned}
& \mathrm{Os}^{\mathrm{O}}(\mathrm{CPh})(\mathrm{CO})\left(\mathrm{PPh}_{3}\right)_{2} \mathrm{Cl}+\underset{\mathrm{Os}}{+\mathrm{HCl}(\mathrm{CHPh})(\mathrm{CO})\left(\mathrm{PPh}_{3}\right) \mathrm{Cl}_{2}} \text { [ref. 49] }
\end{aligned}
$$

\subsubsection{Ligand isomerization}

A ligand which is reduced in the MLCT state may participate in isomerization reactions. Subsequent back electron transfer yields the isomerized complex. For example MLCT excitation which terminates at the $\pi^{*}$ orbitals of an olefin leads to a weakening of the double bond. As a result the coordinated olefin can undergo a trans/cis isomerization. e.g., eqn. (36):

$$
\begin{aligned}
& {\left[\mathrm{Ru}^{\mathrm{II}} \text { (bipy) }{ }_{2} \text { (trans-4-styrylpyridine) }{ }_{2}\right]^{2+} \rightarrow} \\
& {\left[\mathrm{Ru}^{\mathrm{II}} \text { (bipy) }{ }_{2} \text { (cis-4-styrylpyridine) }{ }_{2}\right]^{2+} \quad \text { [ref . 129] }}
\end{aligned}
$$

Isomerizations with the participation of ligands were also observed following MLCT excitation of carbene complexes., e.g, equation (37):

$$
\begin{aligned}
& \text { anti }-(\mathrm{OC})_{5} \mathrm{Cr}=\mathrm{C}\left(\mathrm{OCH}_{3}\right) \mathrm{Ph} \quad \rightarrow \\
& \text { syn }-(\mathrm{OC})_{5} \mathrm{Cr}=\mathrm{C}\left(\mathrm{OCH}_{3}\right) \mathrm{Ph} \quad \text { [ref. 130] }
\end{aligned}
$$

\subsubsection{Acid-base reactions}

MLCT excitation increases the electron density and hence the basicity of the ligand which the electron is transfered to. A proton can be accepted by this ligand and again released when the complex has returned to the ground state $[4,6]$.

$$
\mathrm{M}-\mathrm{L} \rightarrow\left(\mathrm{M}^{+}-\mathrm{L}^{-}\right)^{*} \stackrel{\mathrm{H}^{+}}{\rightarrow}\left(\mathrm{M}^{+}-\mathrm{LH}\right)^{*} \rightarrow \mathrm{M}-\mathrm{L}+\mathrm{H}^{+}
$$

Such acid-base reactions take place at the carboxylic groups of suitable ligands such as $\mathrm{L}-\mathrm{L}=2,2^{\prime}$-bipyridine-4,4'-dicarboxylic acid. e.g. $\left[\mathrm{Ru} \text { (bipy) }{ }_{2}(\mathrm{~L}-\mathrm{L})\right]^{2+}[131]$. In acidic $\mathrm{D}_{2} \mathrm{O}$ solutions of the $\mathrm{Ru}(\mathrm{II})$-complex $\left[\mathrm{Ru}^{\mathrm{II}}\left(\mathrm{NH}_{3}\right)_{5}\right.$ (pyridine) ${ }^{2+}$ a light-induced $\mathrm{H} / \mathrm{D}$ exchange occurs at the pyridine ligand $[10,132]$. This reaction is also attributed to the enhanced basicity of the coordinated pyridine in the MLCT excited state.

\subsubsection{Ligand dissociation/substitution}

Generally, MLCT states are considered not to be dissociative since M-L $\sigma$ orbitals are usually not involved in MLCT transitions. However, if 
$\pi$-bonding is important $\pi-\pi^{*}$ MLCT excitation could result in the dissociation of a metal-ligand bond. A case in question is the photolysis of $\mathrm{Ni}(\mathrm{CO})_{4}$.

$$
\mathrm{Ni}(\mathrm{CO})_{4} \rightarrow \mathrm{Ni}(\mathrm{CO})_{3}+\mathrm{CO} \quad \text { [ref. 133] }
$$

In the presence of a potent ligand a substitution takes place [134]. Owing to the $\mathrm{d}^{10}$ configuration at the metal LF states do not exist. The photoreactivity of $\mathrm{Ni}(\mathrm{CO})_{4}$ was attributed to $3 \mathrm{~d} \rightarrow 4 \mathrm{~s}$ [4] or MLCT [43] excited states.. More recent calculations suggest that ds states can be excluded as reactive states because they occur at too high energies [51].

Complexes of the type $\mathrm{Ni}\left(\mathrm{CO}_{2}\right)(\mathrm{DAB})$ with $\mathrm{DAB}=1$,4-diazabutadiene $(\mathrm{RN}=\mathrm{CH}-\mathrm{CH}=\mathrm{RN})$ are further examples of dissociative MLCT states $[135,136]$. MLCT excitation leads to the breakage of Ni-N or Ni-CO bonds.

While dissociations seem to be rather exceptional associative substitutions are much more common for MLCT states. The increased positive charge at the metal facilitates a nucleophilic attack by a substituting ligand. The following photoreactions were shown to proceed by an associative substitution.

$$
\begin{aligned}
& \mathrm{W}(\mathrm{CNR})_{6}+\mathrm{py} \rightarrow \mathrm{W}(\mathrm{CNR})_{5} \mathrm{py}+\mathrm{CNR} \text { [ref. 4,83] } \\
& \mathrm{Co}(\mathrm{CO})_{3} \mathrm{NO}+\mathrm{PPh}_{3} \rightarrow \mathrm{Co}(\mathrm{CO})_{2}(\mathrm{NO}) \mathrm{PPh}_{3}+\mathrm{CO} \text { [ref.137] (41) } \\
& \mathrm{W}(\mathrm{CO})_{4}(\alpha \text {-diimine })+\mathrm{PR}_{3} \rightarrow \\
& \mathrm{W}(\mathrm{CO})_{3}(\alpha \text {-diimine }) \mathrm{PR}_{3}+\mathrm{CO} \quad \text { [ref. 135,138] }
\end{aligned}
$$

Even the photoaquation of Zeise's salt (equation 43) which is generally assumed to originate from a LF state may take place by an associative mechanism in a MLCT excited state $[47,139]$ :

$$
\left[\mathrm{PtCl}_{3} \mathrm{C}_{2} \mathrm{H}_{4}\right]^{-}+\mathrm{H}_{2} \mathrm{O} \rightarrow\left[\mathrm{PtCl}_{3} \mathrm{H}_{2} \mathrm{O}\right]^{-}+\mathrm{C}_{2} \mathrm{H}_{4}
$$

\subsection{MMCT}

\subsection{1. $M_{\text {red }}{ }^{-L-M_{o x}}$}

Light absorption by MMCT bands of heteronuclear ligand-bridged complexes is well known to induce photoredox reactions [13,60]. Suitable electron acceptors include $\mathrm{Co}$ (III) compounds while cyano complexes of $\mathrm{Fe}(\mathrm{II}), \mathrm{Ru}(\mathrm{II})$, and $\mathrm{Os}(\mathrm{II})$ may be used as donors., e.g., equation (44):

$$
\begin{aligned}
& {\left[\left(\mathrm{NH}_{3}\right)_{5} \mathrm{Co}^{\mathrm{III}}-\mathrm{NC}-\mathrm{Ru}^{\mathrm{II}}(\mathrm{CN})_{5}\right]^{-}} \\
& \mathrm{Co}^{2+}+5 \mathrm{NH}_{3}+\left[\mathrm{Ru}^{\mathrm{III}}(\mathrm{CN})_{6}\right]^{3-} \quad[\text { ref. 61] }
\end{aligned}
$$


This reaction can be viewed as a special case of the redox decomposition of $\mathrm{Co}^{\mathrm{III}}\left(\mathrm{NH}_{3}\right)_{5} \mathrm{X}$ complexes with $\mathrm{X}=\mathrm{Ru}(\mathrm{CN})_{6}{ }^{4-}$. If the ammonia ligands at $\mathrm{Co}$ (III) are replaced by cyanide the photolysis takes a different course (cf. equation 45):

$$
\begin{array}{r}
{\left[(\mathrm{NC})_{5} \mathrm{Co}^{\mathrm{III}}-\mathrm{CN}-\mathrm{Ru}^{\mathrm{II}}(\mathrm{CN})_{5}\right]^{6-}} \\
{\left[\mathrm{Co}^{\mathrm{II}}(\mathrm{CN})_{5}\right]^{3-}+}
\end{array}
$$

MMCT excitation of the binuclear complex leads to primary redox products which do not undergo a decomposition. An efficient recombination by inner-sphere electron transfer regenerates the starting binuclear complex. However, in the presence of $\mathrm{O}_{2}$ the strongly reducing $\mathrm{Co}$ (II) complex is intercepted irreversibly:

$$
2\left[\mathrm{Co}^{\mathrm{II}}(\mathrm{CN})_{5}\right]^{3-}+\mathrm{O}_{2} \rightarrow\left([\mathrm{NC})_{5} \mathrm{Co}^{\mathrm{III}} \mathrm{O}_{2} \mathrm{Co}^{\mathrm{II}}(\mathrm{CN})_{5}\right]^{6-}
$$

In suitable cases MMCT excitation yields multi-electron redox products, e.g. equation (47)

$$
\begin{aligned}
& {\left[(\mathrm{NC})_{5} \mathrm{Fe}^{\mathrm{II}}-\mathrm{CN}-\mathrm{Pt}^{\mathrm{IV}}\left(\mathrm{NH}_{3}\right)_{4}-\mathrm{NC}-\mathrm{Fe}{ }^{\mathrm{II}}(\mathrm{CN})_{5}\right]^{4-} \rightarrow} \\
& 2\left[\mathrm{Fe}^{\mathrm{III}}(\mathrm{CN})_{6}\right]^{3-}+\left[\mathrm{Pt}^{\mathrm{II}}\left(\mathrm{NH}_{3}\right)_{4}\right]^{2+}
\end{aligned}
$$

Reactive MMCT states cannot only be generated by direct light absorption into MMCT bands but also by other processes [60]. The absorption spectrum of $\left(\mathrm{NH}_{3}\right)_{5} \mathrm{Co}{ }^{\mathrm{III}}$-pyz-Fe ${ }^{\mathrm{II}}(\mathrm{CN})_{5}$ (pyz = pyrazine) does not display a MMCT bad which seems to be obscured by an intense Fe(II) $\rightarrow$ pyz MLCT absorption. Nevertheless, MLCT excitation leads to the same products which should be obtained by direct MMCT excitation.

$$
\begin{aligned}
& \left(\mathrm{NH}_{3}\right)_{5} \mathrm{Co}^{\mathrm{III}}-\text { pyz-Fe }{ }^{\mathrm{II}}(\mathrm{CN})_{5} \\
& \mathrm{Co}^{2+}+5 \mathrm{NH}_{3}+\mathrm{Fe}^{\mathrm{III}}(\mathrm{CN})_{5}(\mathrm{pyz})^{2-} \quad \text { [ref. 142] }
\end{aligned}
$$

It can be concluded that the reactive MMCT state is reached by radiationless deactivation from the MLCT state. Homobinuclear complexes such as $\mathrm{Mn}_{2}(\mathrm{CO})_{10}$ with a direct metal-metal bond are split homolytically by $\sigma \sigma *(\mathrm{M}-\mathrm{M})$ excitation [4,7]. In heteronuclear complexes which are characterized by a polar metal-metal bond this $\sigma \sigma^{*}$ excitation involves a CT from the donor to the acceptor metal. MMCT $\left(\sigma \sigma^{*}\right)$ excitation leads to a homolytic bond splitting which may also be viewed as a redox reaction.,e.g., equation (49):

$$
\begin{aligned}
& \mathrm{Ph}_{3} \mathrm{PAu}_{-} \mathrm{I}_{-}{ }^{-\mathrm{I}}(\mathrm{CO})_{4} \rightarrow \\
& \mathrm{PPh}_{3}+\mathrm{Au}^{0}+1 / 2 \mathrm{Co}_{2}^{0}(\mathrm{CO})_{8} \text { [ref. 64] }
\end{aligned}
$$


The coupling of the $\mathrm{Co}(\mathrm{CO})_{4}$ radicals which are produced in the primary photochemical step seems to be the product-forming step of this photolysis. The trinuclear complexes $(\mathrm{OC})_{4} \mathrm{Co}^{-\mathrm{I}}-\mathrm{M}^{\mathrm{II}}-\mathrm{Co}^{-\mathrm{I}}(\mathrm{CO})_{4}$ wih $\mathrm{M}=\mathrm{Zn}, \mathrm{Cd}, \mathrm{Hg}$ [65] and $(\mathrm{NC})_{5} \mathrm{Co}_{-}{ }_{-} \mathrm{HgII}_{-} \mathrm{Co}^{\mathrm{I}}(\mathrm{CN})_{5}{ }^{6-}$ [62] undergo similar photoredox reactions upon $\sigma \sigma^{*}$ MMCT excitation.

\subsection{LLCT}

LLCT excitation of $\mathrm{Pt}$ (bipy)(tdt) with tdt $=3,4$-toluenedithiolate in $\mathrm{CHCl}_{3}$ leads to a photooxidation [87] (equation 50):

$$
\left.\mathrm{Pt}^{\mathrm{II}} \text { (bipy)(tdt }{ }^{2-}\right)+\mathrm{CHCl}_{3} \rightarrow \mathrm{Pt}^{\mathrm{II}}(\text { bipy })\left(\mathrm{tdt}^{-}\right)+\mathrm{Cl}^{-}+\mathrm{CHCl}_{2}
$$

In analogy to MLCT states the reduced bipy ligand which is obtained by ( $\mathrm{tdt}^{2-} \rightarrow$ bipy) LLCT excitation donates its excess electron to the solvent which undergoes an irreversible reduction. The oxidized complex is only stable at low temperatures. It decomposes under ambient conditions.

Complexes of the type $\mathrm{Zn}^{\mathrm{II}}(\mathrm{R}-\mathrm{DAB}) \mathrm{R}_{2}$ ' with $\mathrm{R}-\mathrm{DAB}=1$,4-diaza-1,3butadienes and $\mathrm{R}^{\prime}=$ alkyl or aryl anions photolyze to redox product which clearly reflect the charge distribution in the $\mathrm{R}^{\prime} \rightarrow$ R-DAB LLCT excited state [143] (equation 51):

$$
\mathrm{Zn}^{\mathrm{II}}(\mathrm{R}-\mathrm{DAB}) \mathrm{R}_{2}^{\prime} \rightarrow \mathrm{Zn}^{\mathrm{II}}\left(\mathrm{R}-\mathrm{DAB}^{-}\right) \mathrm{R}^{\prime}+\cdot \mathrm{R}^{\prime}
$$

The primary product $\mathrm{Zn}\left(\mathrm{R}-\mathrm{DAB}^{-}\right) \mathrm{R}^{\prime}$ which can be generated also thermally was identified by ESR spectroscopy. The stability of this radical depends on the nature of $R$ and $R^{\prime}$.

\subsection{ILCT}

IL excitation of $\mathrm{Pt}(\mathrm{l} \text {-naphthylamine })_{2} \mathrm{Cl}_{2}$ involves a shift of electron density from the Pt-N bond into the aromatic ring of the naphthyl moiety. Such an IL transition can thus be also viewed as an ILCT excitation [73]. Since the naphthylamine ligand looses its coordinating ability in the excited state the complex undergoes a photosubstitution of this ligand.

\section{Reactive Intermediates Generated by CT Excitation}

In this section a short survey of reactive intermediates generated by CT excitation is given. The intermediates are classified according to some important properties which are also relevant to catalytic applications. The existence of reactive intermediates has not always been established unambiguously. However, in many cases intermediates were detected and 
characterized by suitable techniques such as flash photolysis and lowtemperature matrix isolation.

\subsection{COORDINATIVELY UNSATURATED COMPLEXES}

Generally, coordinatively unsaturated complexes are obtained by the release of a ligand induced by LF excitation [2-6]. However, CT states may also initiate the formation of such species. For example, $\operatorname{Cr}(\mathrm{CO})_{5}$ which is usually produced by $\mathrm{LF}$ excitation of $\mathrm{Cr}(\mathrm{CO})_{6}[4,43]$ is also generated from LMCT states of $\mathrm{Cr}(\mathrm{CO})_{5} \mathrm{I}$ [25]. $\mathrm{Cr}(\mathrm{CO})_{5}$ is rather reactive but can be stabilized by the addition of a sixth ligand. LMCT excitation of $\mathrm{Pt}\left(\mathrm{PPh}_{3}\right)_{2}\left(\mathrm{~N}_{3}\right)_{2}[117,144]$ or $\mathrm{Pt}_{2}\left(\mathrm{PR}_{3}\right)_{2} \mathrm{C}_{2} \mathrm{O}_{4}$ with $\mathrm{R}=\mathrm{Ph}[116,117]$ or alkyl [118] leas to a reductive elimination with the formation of $\mathrm{Pt}^{0}\left(\mathrm{PR}_{3}\right)_{2}$. This coordinatively unsaturated product is stable only in low-temperature matrices but undergoes oxidative addition reactions with many substrates [118].

\subsection{ELECTRONS}

As described above many reducing anions [6,37,38,121], especially cyano complexes [122-124] such as $\mathrm{Fe}(\mathrm{CN})_{6}{ }^{4-}$ produce solvated electrons upon MLCT (or CTTS) excitation. These electrons are, of course, very reactive and can be intercepted by a variety of scavengers such as $\mathrm{N}_{2} \mathrm{O}$ or $\mathrm{CHCl}_{3}$.

\subsection{ATOMS}

Palladium, platinum, silver, gold, and mercury atoms are formed by LMCT excitation of suitable complexes such as $\left[\mathrm{Pd}\left(\mathrm{N}_{3}\right)_{4}\right]^{2-},\left[\mathrm{Pt}\left(\mathrm{N}_{3}\right)_{4}\right]^{2-}$, $\operatorname{Ag}\left(\mathrm{PPh}_{3}\right) \mathrm{N}_{3},\left[\mathrm{Au}\left(\mathrm{N}_{3}\right)_{2}\right]^{-}$, and $\left[\mathrm{Hg}\left(\mathrm{N}_{3}\right)_{3}\right]^{-}[27,106,145]$. Generally, the metal atoms are rather energy-rich. They agglomerate usually to larger particles which appear as colloids, suspensions, or thin films. In the presence of appropriate compounds the metal atoms participate in addition or insertion reactions [106], e.g., cf. equations $(52,53)$ :

$$
\begin{aligned}
& \mathrm{Pt}^{0}+\mathrm{C}_{3} \mathrm{H}_{5} \mathrm{Cl} \rightarrow 1 / 4\left[\mathrm{C}_{3} \mathrm{H}_{5} \mathrm{PtCl}_{4}\right. \\
& \mathrm{Pd}^{0}+\mathrm{C}_{3} \mathrm{H}_{5} \mathrm{Cl} \rightarrow 1 / 2\left[\mathrm{C}_{3} \mathrm{H}_{5} \mathrm{PdCl}\right]_{2}
\end{aligned}
$$

Owing to their s electron configuration mercury atoms are less reactive and are stable in many solvents such as alkanes and water under ambient conditions $[27,146,147]$. However, the solubility of atomic mercury is rather low $\left(\approx 10^{-7} \mathrm{M}\right)$. 
Non-metallic atoms were also observed as photoproducts following CT excitation. The LMCT photolysis of $\mathrm{Pt}(\mathrm{CN})_{4}\left(\mathrm{~N}_{3}\right)_{2}{ }^{2-}$ generates azide radicals which decompose to $\mathrm{N}_{2}$ and nitrogen atoms $[114,115]$. When the irradiation is carried out in low-temperature matrices the nitrogen atoms are stable and can be conveniently identified by ESR spectroscopy.

In many cases LMCT excitation of halide complexes yields halogen atoms in the primary photochemical step. Halogen atoms $\mathrm{X}$ are difficult to detect under ambient conditions, but they are readily identified as addition products with halide anions $\left(\mathrm{X}+\mathrm{X}^{-} \rightarrow \mathrm{X}_{2}^{-}\right)$which absorb strongly in the near ultraviolet [94].

\subsection{METAL-BASED RADICALS}

A homolysis of metal-ligand or polar metal-metal bonds can be achieved by LMCT or MMCT excitation, respectively. The metal-based radicals which are thus obtained undergo a variety of secondary reactions. Many of these intermediates are kinetically labile and yield decomposition or substitution products. Moreover, frequently they are strong reductants or oxidants and engage in redox reactions. Owing to their radical nature they participate in radical coupling processes including recombination reactions. These typical properties of such metal-based radicals are illustrated by a few examples.

LMCT excitation of $\mathrm{Co} I I I\left(\mathrm{NH}_{3}\right)_{5} \mathrm{X}^{2+}$ with $\mathrm{X}=$ halide or pseudohalide yields the complex fragment $\mathrm{CoII}\left(\mathrm{NH}_{3}\right)_{5}{ }^{2+}$ which is kinetically very labile $[2,5,94]$. Co(II)-ammine complexes decompose in aqueous solution to $\mathrm{Co}^{2+}$ and ammonia with a rate constant $\mathrm{k}>10^{6} \mathrm{~s}^{-1}$ [95]. The LMCT photolysis of $\mathrm{PtCl}_{6}{ }^{2-}$ and other $\mathrm{Pt}(\mathrm{IV})$ complexes leads to the formation of $\mathrm{Pt}^{\mathrm{III}} \mathrm{L}_{5}$ intermediates [111-113] which are also kinetically labile and undergo facile ligand substitutions. Since these $\mathrm{Pt}(\mathrm{III})$ radicals can efficiently exchange electrons with $\mathrm{Pt}(\mathrm{IV})$ they catalyze the substitution of inert $\mathrm{Pt}(\mathrm{IV})$ complexes in a chain reaction $[2,10]$. The overall quantum yield for photosubstitution of $\mathrm{PtCl}_{6}{ }^{2-}$ was shown to exceed unity.

Metal carbonyl radicals which are usually obtained by $\sigma \sigma^{*}(\mathrm{M}-\mathrm{M})$ excitation of dimeric metal carbonyls $[4,7]$ may be also generated by MMCT excitation of heteronuclear complexes with a polar metal-metal bond. The radical $\mathrm{Co}(\mathrm{CO})_{4}$ can thus be generated upon light absorption into MMCT bands of $\mathrm{Ph}_{3} \mathrm{PAu}^{\mathrm{I}}-\mathrm{Co}^{-\mathrm{I}}(\mathrm{CO})_{4}[64]$ or $(\mathrm{OC})_{4} \mathrm{Co}^{-\mathrm{I}}-\mathrm{M}^{\mathrm{II}}-\mathrm{Co}^{-\mathrm{I}}(\mathrm{CO})_{4}$ with $\mathrm{M}=$ $\mathrm{Zn}, \mathrm{Cd}$, and $\mathrm{Hg}$ [65]. In the absence of scavengers radical coupling yields finally $\mathrm{Co}_{2}(\mathrm{CO})_{8}$. Since metal carbonyl radicals are substitutionally labile they may also undergo ligand exchange reactions $[148,149]$. The redox 
properties of metal carbonyl radicals are also of considerable importance $[148,149]$.

\subsection{LIGAND-BASED RADICALS}

A variety of typical organic radicals $\cdot R$ can be formed by homolytic metal- $R$ bond cleavage following LMCT excitation. For example, methyl and benzyl radicals are generated by the photolysis of $\mathrm{ReO}_{3}(\mathrm{Me})$ [22] and $\mathrm{Co}(\mathrm{CN})_{5}$ (benzyl) $^{3-}[96]$ respectively. Many other ligand radicals are produced by homolysis (see also above). Radicals of the type $\mathrm{Zn}^{\mathrm{II}}(\mathrm{R}-\mathrm{DAB}-) \mathrm{R}^{\prime}$ with $\mathrm{R}-\mathrm{DAB}=1$,4-diaza-1,3-butadienes and $\mathrm{R}^{\prime}=$ alkyl or aryl are rare cases of ligand radicals which are still coordinated to a metal. These radicals are formed following LLCT excitation of $\mathrm{Zn}^{\mathrm{II}}(\mathrm{R}-\mathrm{DAB}) \mathrm{R}_{2}$ [143].

\subsection{OTHER REACTIVE INTERMEDIATES}

There are many other types of reactive intermediates which are generated by CT excitation, but cannot be assigned to the groups discussed above. For example, LMCT excitation (including an IL contribution) of $\mathrm{Pt}\left(\mathrm{PPh}_{3}\right)_{2} \mathrm{O}_{2}$ leads to the release of $\mathrm{O}_{2}$ in its excited singlet state [150]. Singlet oxygen is well known for its oxidizing properties. The LMCT photolysis of certain azide complexes [107-110] such as $\mathrm{Rh}\left(\mathrm{NH}_{3}\right)_{5} \mathrm{~N}_{3}{ }^{2+}[107,108]$ yields nitrene intermediates (e.g. $\mathrm{Rh}\left(\mathrm{NH}_{3}\right)_{5} \mathrm{~N}^{2+}$ ) following the ejection of $\mathrm{N}_{2}$. These nitrene complexes are very reactive and form stable products by the addition of various compounds (see above).

\subsection{REDOX ISOMERS}

A CT excited complex may be viewed as distinct chemical species if its potential surface has a minimum which is located outside of the potential surface of the ground state. The CT excited complex is then a well-defined redox isomer which reverts back to the ground state by an activated process. Such redox isomers may have a considerable stability and lifetime. In this sense CT states can be regarded as reactive intermediates. Although there is not much known about such redox isomers they are assumed to be formed as transients in many photoreactions. Fo example, MLCT excitation of the carbyne complex $\mathrm{Os}^{0}(\mathrm{CO})\left(\mathrm{PPh}_{3}\right)_{2}(\mathrm{CPh}) \mathrm{Cl}$ was suggested to generate a redox isomer which is formed by a two-electron transfer from $\mathrm{Os}(\mathrm{O})$ to the carbyne ligand [49]. 


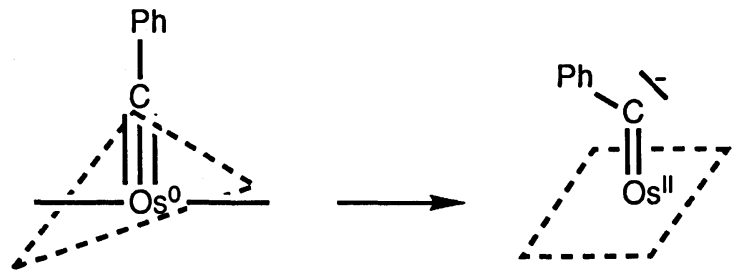

The intermediate is coordinatively unsaturated and susceptible to an electrophilic attack at the carbene anion ligand. Product formation occurs by electrophilic addition at the ligand and completion of the octahedral coordination.
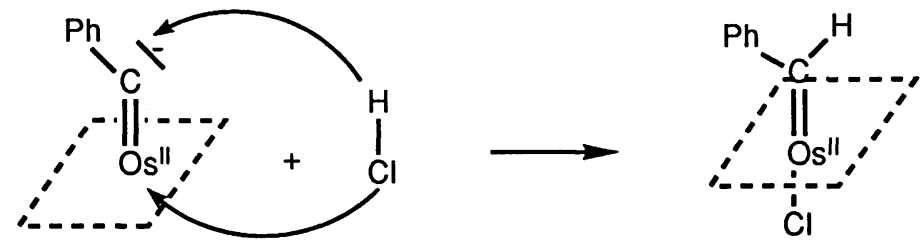

The overall reaction is an oxidative addition of $\mathrm{HCl}$ to a carbyne complex which is transformed to a carbene complex.

\section{Catalytically Active Species Generated by Charge Transfer Excitation}

Many reactive intermediates which are generated by CT excitation are catalytically active. In a few cases this catalytic activity has been already mentioned, e.g. $\mathrm{Pt}(\mathrm{III})$. In other cases the catalytic ability is quite obvious and does not need any further explanation. For example, radicals can initiate polymerizations irrespective of their source. However, catalysts are not necessarily reactive species under non-catalytic conditions. For special applications the photochemical formation of such catalysts offers advantages or is even required. The base-generated photoinitiation for deep-UV lithography is an important application of this type [151]. The LMCT photolysis of $\mathrm{Co}$ (III) ammine complexes liberates efficiently ammonia only at those locations which are not masked. At the light exposed regions an image formation by a base-catalyzed cross-linking takes place. The silver halide photography may be taken as a further example for the photochemical production of a catalyst. Although the light-sensitivity of silver halides is a solid state property it can be also explained in terms of reactive LMCT states. At the light-exposed positions metallic silver nuclei are formed which 
catalyze the further thermal reduction to silver during the development of the film.

\section{Conclusion and Outlook}

CT excitation of metal complexes can yield reactive intermediates which are characterized by their redox activity and substitutional lability. Moreover, these species are frequently radicals. Owing to these properties such intermediates are known or anticipated to act as catalysts. For some important applications the photochemical generation of catalysts offers distinct advantages over other methods. Our present knowledge provides a good basis for a further development of this area.

Institut für Anorganische Chemie,

Universität Regensburg, 8400 Regensburg (Germany)

\section{References}

1. A.B.P. Lever: Inorganic Electronic Spectroscopy, Elsevier, Amsterdam (1984).

2. V. Balzani and V. Carassiti: Photochemistry of Coordination Compounds, Academic Press, New York (1970).

3. A.W. Adamson and P.D. Fleischauer (eds.): Concepts of Inorganic Photochemistry, Wiley-Interscience, New York (1975).

4. G.L. Geoffroy and M.S. Wrighton: Organometallic Photochemistry, Academic, New York (1979).

5. G.J. Ferraudi: Elements of Inorganic Photochemistry, Wiley-Interscience, New York (1988).

6. J. Sykora and J. Sima: Coord. Chem. Rev., 107, 1 (1990)

7. T.J. Meyer and J.V. Caspar: Chem. Rev., 85, 187 (1985)

8. A. Vogler, A. Paukner and H. Kunkely: Coord. Chem. Rev., 57, 285 (1990)

9. C. Kutal: Coord. Chem. Rev., 99, 213 (1990)

10. P.C. Ford, R.E. Hintze, and J.D. Petersen, in ref. 3, p. 203. 
11. A. Vogler and A. Kern: Ber. Bunsenges. Phys. Chem., 83, 500 (1979)

12. M.A. Fox and M. Chanon (eds.): Photoinduced Electron Transfer, Elsevier, Amsterdam, part D.

13. A. Vogler, A.H. Osman and H. Kunkely: Coord. Chem. Rev., 64, 159 (1985)

14. H. Hennig, D. Rehorek and R.D. Archer: Coord. Chem. Rev.,61, 1 (1985)

15. V. Balzani, N. Sabbatini and F. Scandola: Chem. Rev., 86, 319 (1986)

16. H. Hennig, D. Rehorek and R. Billing: Comments Inorg. Chem. 8, 63 (1988)

17. A. Vogler and H. Kunkely: Top. Curr. Chem., 158, 1 (1990)

18. R. Billing, D. Rehorek and H. Hennig: Top. Curr. Chem., 158, 151 (1990)

19. (a) C.K. Jorgensen: Modern Aspects of Ligand Field Theory, NorthHolland (1971); (b) C.K. Jorgensen: Oxidation Numbers and Oxidation States, Springer-Verlag, New York (1968); (c) C.K. Jorgensen: Absorption Spectra and Chemical Bonding in Complexes, Pergamon, Oxford (1962)

20. A. Vogler and H. Kunkely: Comments Inorg. Chem., 9, 201 (1990)

21. C.K. Jorgensen: Adv. Chem. Phys., 5, 33 (1963)

22. H. Kunkely, T. Türk, C. Teixeira, C. de Meric de Bellefon, W.A. Herrmann and A. Vogler: Organometallics, 10, 2090 (1991)

23. J.J. Alexander and H.B. Gray: J. Am. Chem. Soc., 90, 4260 (1968)

24. E. Verdonck and L.G. Vanquickenborne: Inorg. Chem., 13, 762 (1974)

25. H. Kunkely and A. Vogler: J. Organomet. Chem., 378, C15 (1989)

26. (a). M.E. Koutek and W.R. Mason: Inorg. Chem., 19, 648 (1980); (b) M.M. Savas and W.R. Mason: Inorg. Chem., 26, 301 (1987)

27. H. Kunkely and A. Vogler: Polyhedron., 8, 2731 (1989)

28. A. Vogler and H. Nikol: Pure Appl. Chem., 64, 1311 (1992)

29. A. Vogler, A. Paukner and H. Kunkely: Coord. Chem. Rev., 97, 285 (1990)

30. R.A. Walton, R.W. Matthews and C.K. Jorgensen: Inorg. Chim. Acta ., 1, 355 (1967)

31. P.N. Schatz, P.J. Stephens, G.N. Henning and A.J. McCaffery: Inorg. Chem., 7, 1247 (1968)

32. D.A. Couch, C.J. Wilkins, G.R. Rossmann and H.B. Gray: J. Am. Chem. Soc., 92, 307 (1970)

33. D.J. Stufkens: Rec. Trav. Chim., 89, 1185 (1970)

34. J.T. Bell and R.E. Biggers: J. Mol. Spectrosc.,, 18, 247 (1965)

35. C.K. Jorgensen and R. Reisfeld: Struct. Bonding (Berlin), 50, 136 (1982)

36. Y. Haas, G. Stein and M. Tomkiewicz: J. Phys. Chem., 74, 2558 (1970) 
37. M. Fox in ref. 3, p. 333.

38. C. Gianotti, S. Gaspard and P. Krausz in ref. 12, p. 200.

39. G. Blasse: Struct. Bonding (Berlin)., 76, 153 (1991)

40. K.L. Stevenson, J.L. Braun, D.D. Davis, K.S. Kurtz and R.I. Sparks: Inorg. Chem., 27, 3472 (1988)

41. K. Kalyanasundaram: Photochemistry of Polypyridine and Porphyrin Complexes, Academic Press, London (1992).

42. A. Vogler and H. Kunkely: Inorg. Chim. Acta , 150, 1 (1988)

43. A. Vogler in ref. 3, p. 269.

44. R.W. Wright and A. Vogler: J. Organomet. Chem., 160, 197 (1978)

45. P.M. Gidney, R.D. Gillard and B.T. Heaton: J. Chem. Soc., Dalton Trans., 132 (1973)

46. R.G. Denning, F.R. Hartley and L.M. Venanzi: J. Chem. Soc. (A), 1322 (1967)

47. N. Rösch, R.P. Messmer and K.H. Johnson: J. Am. Chem. Soc., 96, 3855 (1974)

48. M. Dartiguenave, Y. Dartiguenave and H.B. Gray: Bull. Soc. Chim. Fr., 12, 4223 (1969)

49. A. Vogler, J. Kisslinger and W.R. Roper: Z. Naturforsch., 38b, 1506 (1983)

50. A.B.P. Lever, G.A. Ozin, A.J. Hanlan, W.J. Power and H.B. Gray: Inorg. Chem., 18, 2088 (1970)

51. M. Kotzian, N. Rösch, H. Schroder, M.C. Zerner: J. Am. Chem. Soc., 111, 7687 (1989)

52. H. Kunkely and A. Vogler: J. Organomet. Chem., 431, C42 (1992)

53. D.J. Casadonte, D.R. McMillin: J. Am. Chem. Soc., 109, 331 (1987)

54. (a). W.R. Mason: J. Am. Chem. Soc., 98, 5182 (1976); (b) S.K. Chastain and W.R. Mason: Inorg. Chem., 21, 3717 (1982)

55. H. Kunkely, A. Paukner, A. Vogler: Polyhedron, 8, 2937 (1989)

56. D. Brown (ed.): Mixed-Valence Compounds, Reidel, Dordrecht (1980).

57. C. Creutz: Progr. Inorg. Chem., 30, 1 (1980)

58. N.S. Hush: Progr. Inorg. Chem., 8, 391 (1967)

59. A. Vogler, A.H. Osman and H. Kunkely: Coord. Chem. Rev., 64, 159 (1985)

60. A. Vogler in ref. 12, p. 179.

61. A. Vogler and H. Kunkely: Ber. Bunsenges. Phys. Chem., 79, 83 (1975)

62. H. Kunkely, G. Stochel and A. Vogler: Z. Naturforsch., 44b, 145 (1989)

63. C.I. Browne, R.P. Craig and N. Davidson: J. Am. Chem. Soc., 73, 1946 (1951) 
64. A. Vogler and H. Kunkely: Z. Naturforsch., 44b, 132 (1989)

65. A. Vogler and H. Kunkely: J. Organomet. Chem., 355, 1 (1988)

66. G.J. Stor, D.J. Stufkens and A. Oskam: Inorg. Chem., 31, 1319 (1992)

67. J. A. McCleverty: Progr. Inorg. Chem., 10, 49 (1968)

68. R.P. Burns and C.A. McAuliffe: Adv. Inorg. Chem. Radiochem., 22, 303 (1979)

69. T.R. Miller and I.G. Dance: J. Am. Chem. Soc., 95, 6970 (1973)

70. R. Benedix, H. Hennig, H. Kunkely and A. Vogler: Chem. Phys. Lett., 175, 483 (1990)

71 . A. Vogler and H. Kunkely: Inorg. Chim. Acta , 54, L 273 (1981)

72. R. Benedix, F. Dietz and H. Hennig: Inorg. Chim. Acta, 147, 179 (1988)

73. A. Vogler and A. Kern: Angew. Chem. Int. Ed. Engl., 15, 625 (1976)

74. P.D. Fleischauer and P. Fleischauer: Chem. Rev., 70, 199 (1970)

75. A.J. Lees: Chem. Rev., 87, 711 (1987)

76. (a). G. Blasse: Struct. Bonding (Berlin), 42, 1 (1980); (b) G. Blasse: Prog. Solid State Chem., 18, 79 (1988)

77. H. Kunkely and A. Vogler: J. Chem. Soc., Chem. Commun., 1204 (1990)

78. T. Türk, U. Resch, M.A. Fox and A. Vogler: Inorg. Chem ., 31, 1854 (1992)

79. T. Türk, U. Resch, M.A. Fox and A. Vogler: J. Phys. Chem., 96, 3818 (1992)

80. A. Vogler and H. Kunkely: Inorg. Chim. Acta,, 53, L215 (1981)

81 . K. Kalyanasundaram: Coord. Chem. Rev., 46, 159 (1982)

82. A.B. Bocarsly, R.E. Cameron, H.-D. Rubin, G.A. McDermott, C.R. Wolff and A. Mayr: Inorg. Chem., 24, 3977 (1985)

83. K.R. Mann, H.B. Gray and G.S. Hammond: J. Am. Chem. Soc., 99, 306 (1977)

84. M. Maestri, D. Sandrini, V. Balzani, L. Chassot, P. Jolliet and A. von Zelewsky: Chem. Phys. Lett., 122, 375 (1985)

85. L. Chassot, A. von Zelewsky, D. Sandrini, M. Maestri and V. Balzani: $J$. Am. Chem. Soc., 108, 6084 (1986)

86. D. Sandrini, M. Maestri, V. Balzani, L. Chassot and A. von Zelewsky: $J$. Am. Chem. Soc., 109, 7720 (1987)

87. A. Vogler and H. Kunkely: J. Am. Chem. Soc., 103, 1559 (1981)

88. (a) K.A. Truesdell and G.A. Crosby: J. Am. Chem. Soc., 107, 1787 (1985); (b) G.A. Crosby, R.G. Highland and K.A. Truesdel: Coord. Chem. Rev., 64, 41 (1985); (c) R. Highland, J.G. Brummer and G.A. Crosby: J. Phys. Chem., 90, 1593 (1986) 
89. T.A. Perkins, D.B. Pourreau, T.L. Netzel and K.S. Schanze: J. Phys. Chem., 93, 4511 (1989)

90. A.W. Adamson, A. V.ogler and I. Lantzke: J. Phys. Chem., 73, 4183 (1969)

91. A. Vogler and A. Kern: Z. Naturforsch., 34b, 271 (1978)

92. A. Vogler and H. Kunkely: Electron and Proton Transfer in Chemistry and Biology (eds. A. Muller, H. Ratajczak, W. Junge and E. Diemann), Elsevier, Amsterdam (1992) p. 31.

93. T.D. Westmoreland, K.S. Schanze, P.E. Neveux, E. Danielson, B.P. Sullivan, P. Chen and T.J. Meyer: Inorg. Chem., 24, 2596 (1985)

94. J.F. Endicott in ref. 3, p. 81.

95. M. Simic and J. Lilie: J. Am. Chem. Soc., 96, 291 (1974)

96. A. Vogler and R. Hirschmann: Z. Naturforsch., 31b, 1082 (1976)

97. V. Balzani, R. Ballardini, N. Sabbatini and L. Moggi: Inorg. Chem., 7, 1398 (1968)

98. F. Scandola, C. Bartocci and M.A. Scandola: J. Am. Chem. Soc., 95, 7898 (1973)

99. J.F. Endicott and G. Ferraudi: J. Am. Chem. Soc., 96, 3681 (1974)

100. B. Kräutler: Helv. Chim. Acta , 67, 1053 (1984)

101. A.L. Poznyak and V.I. Pavlovski: Angew. Chem. Int. Ed. Engl., 27, 789 (1988)

102. W.L. Wells and J.F. Endicott: J. Phys. Chem., 75, 3075 (1971)

103. D.G. Lee, C.R. Moylan, T. Hayashi and J.I. Brauman: J. Am. Chem. Soc., 109, 3003 (1987)

104. A. Vogler and H. Kunkely: Inorg. Chem., 27, 504 (1988)

105. (a) I.S. Ginns and M.C.R. Symons: J. Chem. Soc., Faraday Trans. II, 68, 631 (1972); (b) T.A. Claxton, R.E. Overill and M.C.R. Symons: Mol. Phys., 26, 75 (1973)

106. A. Vogler, C. Quett and H. Kunkely: Ber. Bunsenges. Phys. Chem., 92, 1486 (1988)

107. (a) J.L. Reed, F. Wang and F. Basolo: J. Am. Chem. Soc., 94, 7173 (1972); ( b ) H . D . Gafney, J . L . Reed and F. Basolo: J. Am. Chem. Soc., 95, 7998 (1973); (c) J.L. Reed, H.D. Gafney and F. Basolo: J. Am. Chem . Soc., 96, 1363 (1974)

108. (a) G. Ferraudi and J.F. Endicott: J. Am. Chem. Soc., 95, 2371 (1973);

(b) G. Ferraudi and J.F. Endicott:Inorg. Chem., 12, 2389 (1973)

109. R.M. Dahlgren and J.I. Zink: Inorg. Chem., 18, 597 (1979)

110. J.I. Zink: Inorg. Chem., 14, 446 (1975) 
111. (a) G.A. Shagisultanova: Koord. Khim., 7, 1527 (1981) (in Russian); (b) I.I. Blinov and G.A. Shagisultanova: Koord. Khim., 8, 191 (1982) (in Russian); (c) K.P. Balashev, I.I. Blinov and G.A. Shagisultanova: Koord. Khim., 13, 1674 (1987) (in Russian).

112. R.C. Wright and G.S. Laurence: J. Chem. Soc., Chem. Commun., 132 (1972)

113. (a) V.P. Grivin, I.V. Khmelinski, V.F. Plyusnin, M. Mitewa and P.R. Bontchev: J. Photochem. Photobiol. A: Chem., 62, 15 (1991); (b) V.P. Grivin, I.V. Khmelinski, V.F. Plyusnin, M. Mitewa, J. Angelova, E. Dimitrova and P. R. Bontchev: J. Photochem. Photobiol. A: Chem. 63, 7 (1992) and references cited therein.

114. A. Vogler, A. Kern, B. Fusseder and J. Hüttermann: Z. Naturforsch., 33b, 1352 (1978)

115. A. Vogler, A. Kern and J. Hüttermann: Angew. Chem. Int. Ed. Engl., 17, 524 (1978)

116. D. M. Blake and C.J. Nyman: J. Am. Chem. Soc., 92, 5359 (1970)

117. A. Vogler, R.E. Wright and H. Kunkely: Angew. Chem. Int. Ed. Engl., 19, 717 (1980)

118. (a) R.S. Paonessa and W.C. Trogler: Organometallics, , 1, 768 (1982); (b) R.S. Paonessa, A.L. Prignano and W.C. Trogler: Organometallics, 4, 647 (1985); (c) W.C. Trogler: The Chemistry of Excited States and Reactive Intermediates (A.B.P. Lever, ed.), p. 177, ACS Symposium Series Nr. 307, American Chemical Society, Washington, D.C. (1986).

119. A. Vogler and A. Paukner: J. Photochem. Photobiol. A: Chem., 46, 227 (1989)

120. A. Vogler and H. Kunkely: Inorg. Chim. Acta, 162, 167 (1989)

121. V. Balzani, F. Bolletta, M.T. Gandolfi and M. Maestri: Top. Curr. Chem., 75,1 (1978)

122. (a) W.L. Waltz, A.W. Adamson and P.D. Fleischauer: J. Am. Chem. Soc., 89, 3923 (1967); (b) W.L. Waltz and A.W. Adamson: J. Phys. Chem., 73, 4250 (1969)

123. (a) M. Shirom and G. Stein: J. Chem. Phys., 55, 3372 (1971); (b) M. Shirom and M. Weiss: J. Chem. Phys., 56, 3170 (1972); (c) 0. Kalisky and M. Shirom: J. Photochem., 7, 215 (1977)

124. A. Horvath, S. Papp and Z. Decsy: J. Photochem., 24, 331 (1984)

125. A. Vogler, W. Losse and H. Kunkely: J. Chem. Soc.,Chem. Commun., 188 (1979)

126. J.D. Carter, K.B. Kingsbury, A. Wilde, T.K. Schoch, C.J. Leep, E.K. Pham and L. McElwee-White: J. Am. Chem. Soc., 113, 2947 (1991) 
127. A. Vogler and H. Kunkely: Angew. Chem. Int. Ed. Engl., 21, 209 (1982)

128. F.W. Grevels and E. Koerner von Gustorf: Liebigs Ann. Chem., 547 (1975)

129. P.P. Zarnegar, C.R. Bock and D.G. Whitten: J. Am. Chem. Soc., 95, 4367 (1973)

130. P.C. Servaas, D.J. Stufkens and A. Oskam: J. Organomet. Chem., 390, 61 (1990)

131. P.A. Lay and W.H.F. Sasse: Inorg. Chem., 23, 4123 (1984)

132. (a) D.A. Chaisson, R.E. Hintze, D.H. Stuermer, J.D. Peterson, D.P. McDonald and P.C. Ford: J. Am. Chem. Soc., 94, 6665 (1972); (b) P.C. Ford, D.A. Chaisson and D.H. Stuermer: J. Chem. Soc., Chem. Commun., 530 (1971)

133. A.J. Rest and J.J. Turner: J. Chem. Soc., Chem. Commun., 1026 (1969)

134. A.J. Rest: J. Organomet. Chem., 40, C76 (1972)

135. D.J. Stufkens: Coord. Chem. Rev., 104, 39 (1990)

136. P.C. Servaas, D.J. Stufkens and A. Oskam: Inorg. Chem., 28, 1780 (1989)

137. W. Evans and J.I. Zink: J. Am. Chem. Soc., 103, 2635 (1981)

138. R.W. Balk, T.L. Snoeck, D.J. Stufkens and A. Oskam: Inorg. Chem., 19, 3015 (1980)

139. P. Natarajan and A.W. Adamson: J. Am. Chem. Soc., 93, 5599 (1971)

140. A. Vogler and H. Kunkely: Ber. Bunsenges. Phys. Chem., 79, 301 (1975)

141. M. Zhou, B.W. Pfennig, J. Steiger, D.V. Engen and A.B. Bocarsly: Inorg. Chem., 29, 2456 (1990)

142. J.M. Malin, D.A. Ryan and T.V. O'Hallotan: J. Am. Chem. Soc., 100, 2097 (1978)

143. M. Kaupp, H. Stoll, H. Preuss, W. Kaim, T. Stahl, G. van Koten, E. Wissing, W.J.J. Smeets and A.L. Spek: J. Am. Chem. Soc., 113, 5606 (1991)

144. (a) H. Hennig, R. Stich, H. Knoll and D. Rehorek: Z. Anorg. Allg. Chem., 576, 139 (1989); (b) H. Knoll, R. Stich, H. Hennig and D.J. Stufkens: Inorg. Chim. Acta , 178, 71 (1990)

145. The photoreduction of chloroplatinum complexes by alcohol leads also to the formation of metallic platinum (R.E. Cameron and A.B. Bocarsly: Inorg. Chem., 25, 2910 (1986)). However, the photolysis is apparently also induced by LF excitation.

146. J.G. Calvert and J.N. Pitts, Photochemistry, Wiley, New York, 1966.

147. W.R. Mason: Inorg. Chem., 27, 437 (1988) 
148. W.C. Trogler (ed.): Organometallic Radical Processes, Elsevier, Amsterdam (1990).

149. (a). A.E. Stiegmann and D.R. Tyler: Coord. Chem. Rev., 63, 217 (1985);

(b) D.R. Tyler: Progr. Inorg. Chem., 36, 125 (1988)

150. A. Vogler and H. Kunkely: J. Am. Chem. Soc., 103, 6222 (1981)

151. C. Kutal and C.G. Willson: J. Electrochem. Soc., 134, 2280 (1987) 